\title{
A Nation of Organizers: The Institutional Origins of Civic Voluntarism in the United States
}

\section{Citation}

Theda Skocpol, Marshall Ganz and Ziad Munson. 2000. A Nation of Organizers: The Institutional Origins of Civic Voluntarism in the United States. The American Political Science Review 94(3): 527-546

\section{Published Version}

http://dx.doi.org/10.2307/2585829

\section{Permanent link}

http://nrs.harvard.edu/urn-3:HUL.InstRepos:12641806

\section{Terms of Use}

This article was downloaded from Harvard University's DASH repository, and is made available under the terms and conditions applicable to Other Posted Material, as set forth at http:// nrs.harvard.edu/urn-3:HUL.InstRepos:dash.current.terms-of-use\#LAA

\section{Share Your Story}

The Harvard community has made this article openly available.

Please share how this access benefits you. Submit a story.

Accessibility 


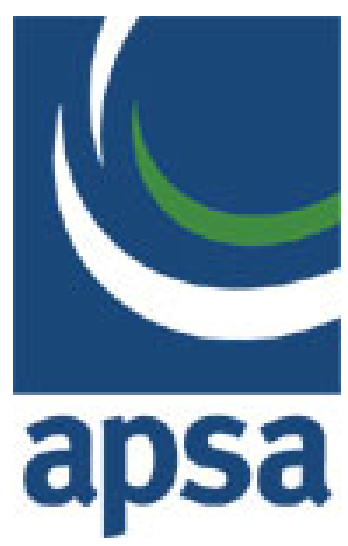

A Nation of Organizers: The Institutional Origins of Civic Voluntarism in the United States Author(s): Theda Skocpol, Marshall Ganz and Ziad Munson

Reviewed work(s):

Source: The American Political Science Review, Vol. 94, No. 3 (Sep., 2000), pp. 527-546

Published by: American Political Science Association

Stable URL: http://www.jstor.org/stable/2585829

Accessed: 04/06/2012 17:27

Your use of the JSTOR archive indicates your acceptance of the Terms \& Conditions of Use, available at http://www.jstor.org/page/info/about/policies/terms.jsp

JSTOR is a not-for-profit service that helps scholars, researchers, and students discover, use, and build upon a wide range of content in a trusted digital archive. We use information technology and tools to increase productivity and facilitate new forms of scholarship. For more information about JSTOR, please contact support@jstor.org. 


\title{
A Nation of Organizers: The Institutional Origins of Civic Voluntarism in the United States THEDA SKOCPOL, MARSHALL GANZ, and ZIAD MUNSON Harvard University .
}

\begin{abstract}
$W$ e challenge the widely held view that classic American voluntary groups were tiny, local, and disconnected from government. Using newly collected data to develop a theoretically framed account, we show that membership associations emerged early in U.S. history and converged toward the institutional form of the representatively governed federation. This form enabled leaders and members to spread interconnected groups across an expanding nation. At the height of local proliferation, most voluntary groups were part of regional or national federations that mirrored the structure of U.S. government. Institutionalist theories suggest reasons for this parallelism, which belies the rigid dichotomy between state and civil society that informs much current discussion of civic engagement in the United States and elsewhere.
\end{abstract}

$\mathbf{P}$ ublic life in the United States has long been rooted in voluntary membership groups as well as competitive elections. From churches and unions to social groups and reform crusades, membership associations have provided paths into active citizenship, allowing Americans to build community, pursue shared goals, and influence social and political affairs. Americans excel at the "knowledge of how to combine" that is the "mother of all other forms of knowledge" in a democracy, marveled Alexis de Tocqueville ([1835-40] 1969, 516-7) in the 1830s. By the 1890s, British visitor James Bryce $(1895,278)$ observed that "associations are created, extended, and worked in the United States more ... effectively than in any other country." Recently, social scientists have used cross-national survey data to document the extraordinary proclivity of Americans to participate in voluntary groups (Almond and Verba 1963; Curtis, Grabb, and Baer 1992; Ladd 1999, 131-6).

Despite longstanding agreement that voluntarism is central to American democracy - and notwithstanding its frequent invocation in theoretical and policy pronouncements-surprisingly little is known about the development of voluntary membership associations in the United States. Students of American political development might have tackled this issue but until now

Theda Skocpol (ts@wih.harvard.edu) is Victor S. Thomas Professor of Government and Sociology; Marshall Ganz is Lecturer in Public Policy, Kennedy School of Government, and Ziad Munson is a PhD candidate, Department of Sociology, Harvard University, Cambridge, MA 02138 .

Financial support for this research was provided by the Ford Foundation, the Russell Sage Foundation, the Pew Charitable Trusts, the John D. and Catherine T. MacArthur Foundation, and the Whitehead Center for International Affairs at Harvard University. We are especially grateful for data collection efforts by Bayliss Camp, Andrew Karch, Cameron Shełdon, David Siu, and Jennifer Oser; we also thank other researchers for the Civic Engagement Project. Librarians and archivists in various cities and associations helped us assemble data. For helpful comments on earlier versions, we thank the APSR Editor and anonymous reviewers as well as Robert Bates, Sheri Berman, Irene Bloemraad, David Collier, Jorge Dominguez, Morris Fiorina, Gerald Gamm, Peter Hall, Ronald Heifetz, Jason Kaufman, Margaret Levi, Lisa Martin, Ted Miguel, Debra Minkoff, Mark Moore, John Padgett, Andrew Polsky, Robert Putnam, Kenneth Shepsle, Bill Skocpol, and Sidney Verba. have focused on class formation, political parties, and public policymaking. In debates now raging about America's civic health, everyone refers to traditions of voluntarism, but assumptions prevail in the absence of systematic evidence.

\section{THE CURRENT WISDOM: SMALL WAS BEAUTIFUL IN AMERICAN CIVIC LIFE}

Classic American voluntary membership groups are widely presumed to have been spontaneous and particular creations, fashioned within relatively bounded local communities; neighbors and friends coalesced outside politics and apart from involvements with extralocal government. Pundits and normative theorists regularly espouse this vision of America's civic past. Peter Drucker $(1993,9)$ contrasts America's tradition of "voluntary group action from below" to "the collectivism of organized governmental action from above," and George Will (1995) portrays voluntary groups as neighborly "little battalions" doing battle with "the federal government's big battalions." "Before the modern age," write conservative political theorists Michael Joyce and William Schambra (1996, 11-2) in a crisp formulation of conventional wisdom, "American life ... was characterized by both its selfcontainment and its cohesiveness. Individuals were closely bound to one another by strong families, tightly knit neighborhoods, and active voluntary and fraternal groups. Through these small, local, 'human-scale' associations, Americans not only achieved a sense of belonging and connectedness but also tackled the full range of social and human problems that today have largely become the province of government." Liberal theorists rarely disparage government, yet communitarians (e.g., Sandel 1996) suggest that national interventions have compromised local civic virtue. As Beem $(1999,197)$ shows in a wide-ranging review of current scholarship, theorists of all stripes focus on local communities and consider "governmental actions and ... large political organizations ... at best irrelevant to, and, at worst, inimical" to democratic civil society. Among empirical scholars, similar presumptions 
span disciplines. Historians portray U.S. voluntary groups as local, informal, and profusely varied-until industrial modernization brought standardization and bureaucracy. Versions vary (cf. Wiebe 1967 and Ryan 1997), but the main story line features the eclipse of once vital particular communities by nationalizing forces (for a critique of such historiography, see Bender 1978). Offering another variant of the standard wisdom, political scientists Gerald Gamm and Robert Putnam $(1999,513)$ use U.S. city directories from 1840 to 1940 to tally groups they assume were "obscure, scattered, and often small." Their analysis reveals that smaller cities and places outside the East had greater numbers of voluntary groups per capita. Reasoning from the theory of social capital outlined in Putnam's Making Democracy Work (1993), Gamm and Putnam $(1999,533,549,551)$ argue that the U.S. "civic core was in the periphery" because associations were "created and sustained most easily" in "slow-growing" communities that were "relatively small and homogeneous."

Indeed, theorists of social capital have become the latest exponents of the small-is-beautiful school of civic virtue. In this perspective "horizontally" but not "vertically" organized groups foster and sustain face-toface networks essential for healthy democracy. "Taking part in a choral society or a bird-watching club can teach self-discipline and an appreciation for the joys of successful collaboration," reasons Putnam (1993, 90); and small groups foster societal trust and governmental efficiency. To test such ideas, Putnam measured the density of purely local sports, recreational, and cultural groups in various regions of Italy. "Local branches of national organizations" were deliberately excluded because "organizations 'implanted' from the outside have a high failure rate," whereas "the most successful" groups are "indigenous ... initiatives in relatively cohesive local communities" (Putnam 1993, 91-2, including n. 35). Invoking widely held ideas about U.S. civic history, Putnam (1993, 91-2) concludes that regions of Italy thick with local recreational and cultural groups "rival Tocqueville's America of congenital joiners."

\section{AN ALTERNATIVE ACCOUNT OF AMERICAN ASSOCIATIONAL DEVELOPMENT}

Small-as-beautiful understandings of America's civic past prevail today, but a quite different account appears in historian Arthur Schlesinger's (1944) classic article, "Biography of a Nation of Joiners." Focusing on "voluntary bodies of sizable membership, reasonably long duration, and fairly large territorial extent," Schlesinger (pp. 2, 25) portrays the development of a "vast and intricate mosaic" of large-scale associations "reaching out with interlocking memberships to all parts of the country."

In colonial America, Schlesinger (1944, 5) argues, voluntary groups were few and usually tied to local church congregations. But the struggle for independence from Britain taught "men from different sections valuable lessons in practical cooperation," and "the adoption of the Constitution stimulated still further applications of the collective principle." A new associational model crystallized in the early 1800 s, a time of flux and experimentation in the democratizing republic. Ambitious organizers developed a standard approach: They chose an "imposing" name, "sent forth ... agents on the wide public," and "multiplied" "subsidiary societies ... over the length and breadth of the land." Associations began to organize along the lines of "the Federal political system, with local units loosely linked together in state branches and these in turn sending representatives to a national body" (Schlesinger 1944, 11). Subsequently, the Civil War brought a "heightened sense of nationality," redoubled "Northern endeavors to plan far-flung undertakings," and so gave "magnified force" to association-building in the late 1800s (Schlesinger 1944, 16).

Although not explicitly theoretical, Schlesinger's overview highlights the role of national organizers who learned from political experience, and it suggests that translocal federations fostered local chapters. What is more, Schlesinger's evidence resonates with the ideas of scholars (e.g., Berman 1997; Evans 1997; Levi 1996; Tarrow 1996a) who criticize social capital theory for downplaying the influence of government in civil society. As Sidney Tarrow $(1996 a, 395)$ puts it, "the character of the state is external" to the social capital model, because "civic capacity" is seen "as a native soil in which state structures grow rather than one shaped by patterns of state building." Reinforcing doubts about such thinking, Schlesinger suggests that American voluntary groups developed in close relationship to the representative and federal institutions of the U.S. state.

\section{UNRESOLVED ISSUES AND NEW EVIDENCE}

Were nationally organized associations prevalent or scarce in America's past, and did translocal linkages encourage or undercut local voluntary groups? What, if anything, did governmental institutions and episodes of nation-state formation have to do with the development of U.S. membership associations? The contrasting perspectives we have reviewed need to be adjudicated with systematic data and methods of analysis. Ideally, we would like to draw a "sample" from a master directory listing membership groups of all types and sizes, past and present. But no such census exists; and post-1955 directories miss many groups that lived and died in the past. Because no straightforward random sample can be drawn, we triangulate, using several sources of data.

To explore Schlesinger's hypotheses more systematically than he was able to do, we consider not just scattered examples but the entire universe of very large U.S. membership associations, using data from an ongoing study (Skocpol et al. 1999) of the origins and development of all U.S. voluntary groups, apart from churches and political parties, that ever enrolled $1 \%$ or more of adults as members. In the larger study, directories and historical works were used to compile the names of groups whose membership might have ex- 
ceeded $1 \%$ of U.S. adults (the baseline includes both genders for mixed associations, but $1 \%$ of men or women for single-gender groups). Data have been uncovered to determine that 58 associations exceeded this threshold. Here we examine 46 groups that recruited $1 \%$ of American men and/or women. at any time prior to the 1940s, when Schlesinger's overview ended. ${ }^{1}$

A study of only very large associations would obviously bias our findings, so we use two additional kinds of evidence. Historical directories and compilations (Breckinridge 1933, Part I; Palmer 1944; Preuss 1924; Schmidt 1980; Stevens 1899) enable us to situate very large groups in relation to other translocal organizations. In addition - and this is the crucial evidentiary aspect of our study - we use city directories to obtain listings of locally present voluntary groups of all kinds (see Appendix B). For the same geographically dispersed set of cities examined by Gamm and Putnam (1999), we ask what proportion of all groups listed in city directories were part of translocal federations. We also probe the relative stability of strictly local versus translocally connected groups. By combining different bodies of data and looking for overlaps between universes of national and local groups, we are able to go well beyond what previous scholars have done. We can document and theorize anew about the relationship of local to translocal association-building in the historical formation of American civil society.

\section{LARGE MEMBERSHIP ASSOCIATIONS: PREVALENCE, FORMS, AND ORIGINS}

Most observers assume that large voluntary associations (apart from political parties and religious denominations) were absent in preindustrial America. But conventional wisdom is mistaken, as Table 1 reveals. Moral crusades and political movements; labor unions and farmers' associations; veterans' and women's groups; recreational and civic associations; and fraternal groups of many sorts-undertakings of each type attracted hundreds of thousands or millions of members. To be sure, some large membership organizations passed out of existence after brief campaigns to attain a policy goal, and others flared up and died down within just a few years. Nevertheless, most of the 46 groups listed in Table $1 \mathrm{fit}$ Schlesinger's conception of large and persistent membership associations. More than two-fifths crossed the $1 \%$ membership threshold before 1900, and more than three-quarters exceeded this mark before 1920. Large voluntary associations have flourished in all eras of U.S. history.

Table 1, which draws on group records, official histories, and scholarly studies (see Appendix A), indicates when and where the first organized unit of

\footnotetext{
1 Twelve other U.S. membership associations crossed the $1 \%$ threshold after 1940. Of these, five were founded and attained very large size between the late 1950 s and the 1990s; seven others were founded before 1940 but grew very large only afterward. Reinforcing the conclusions reported below, six of seven founded before 1940 (and all five founded before 1920) were representative federations with intermediate tiers at the state or regional level.
}

each named association appeared and classifies the aims of the group's founders. In some cases, such as the Independent Order of Odd Fellows (Stillson 1897, 211-4) and the Young Men's Christian Association (Hopkins 1951, 15-9), the founders originally thought they were establishing what we call a local "portal" for a European-based group to pass into the United States. ${ }^{2}$ In other cases, founders envisaged a local group centered in a particular city or state and only later decided to pursue national ambitions. Other founders planned from the beginning to build a truly national association, even if it took some time to realize their plans. Still other founders negotiated combinations of previously formed local or regional groups. The General Federation of Women's Clubs (GFWC), for example, was pulled together in 1890 when the leaders of the Sorosis Club of New York City convened a meeting of about five dozen clubs from across the United States (Wells 1953, chap. 2).

Many scholars assume that combination of preexisting groups must have been the principal way national associations emerged, usually after the U.S. economy became more centralized at the very end of the nineteenth century. But Table 2 shows that the fusion of subnational groups was hardly the typical route by which ultimately large membership associations came into being. Combinations from below account for only $13 \%$ of all foundings of very large groups; and only another one-fifth were originally focused on a particular city or state. Remarkably, in more than three-fifths of cases, associational founders undertook national projects from the start; these launchings occurred from the early 1800 s through the early 1900 s.

\section{Nation-State Formation and Voluntary Membership Federations}

Major junctures of U.S. state formation clearly punctuated the development of translocal civil associations. No national groups emerged in colonial times. Apart from transnational religious denominations, the earliest translocal association was the Masons; lodges sprang up in cities, towns, and military garrisons, and "sovereign grand lodges" formed alongside the government of each colony. But the deeply rooted Masonic grand lodges (which corresponded to the states after the American Revolution) were never able to agree on a nationally unified governing structure (Stillson 1926, 226-7). Certain higher orders affiliated with Masonry eventually adopted unified structures, but basic "blue lodge" Masonry never took this institutional step.

The American Revolution and debates over the Constitution, along with contentious and evangelical religious movements in the new nation, spurred early Americans to organize all kinds of voluntary groups,

\footnotetext{
${ }^{2}$ Two other associations included in tables 1 and 2 also moved into the United States from abroad: The Red Cross was founded as the U.S. national part of an international movement, and the Maccabees started in Ontario, Canada, and very quickly crossed the border with national ambitions in the United States. We classify both as national foundings, reserving the term "portal" for associations originally founded as local U.S. outposts of foreign-centered associations.
} 


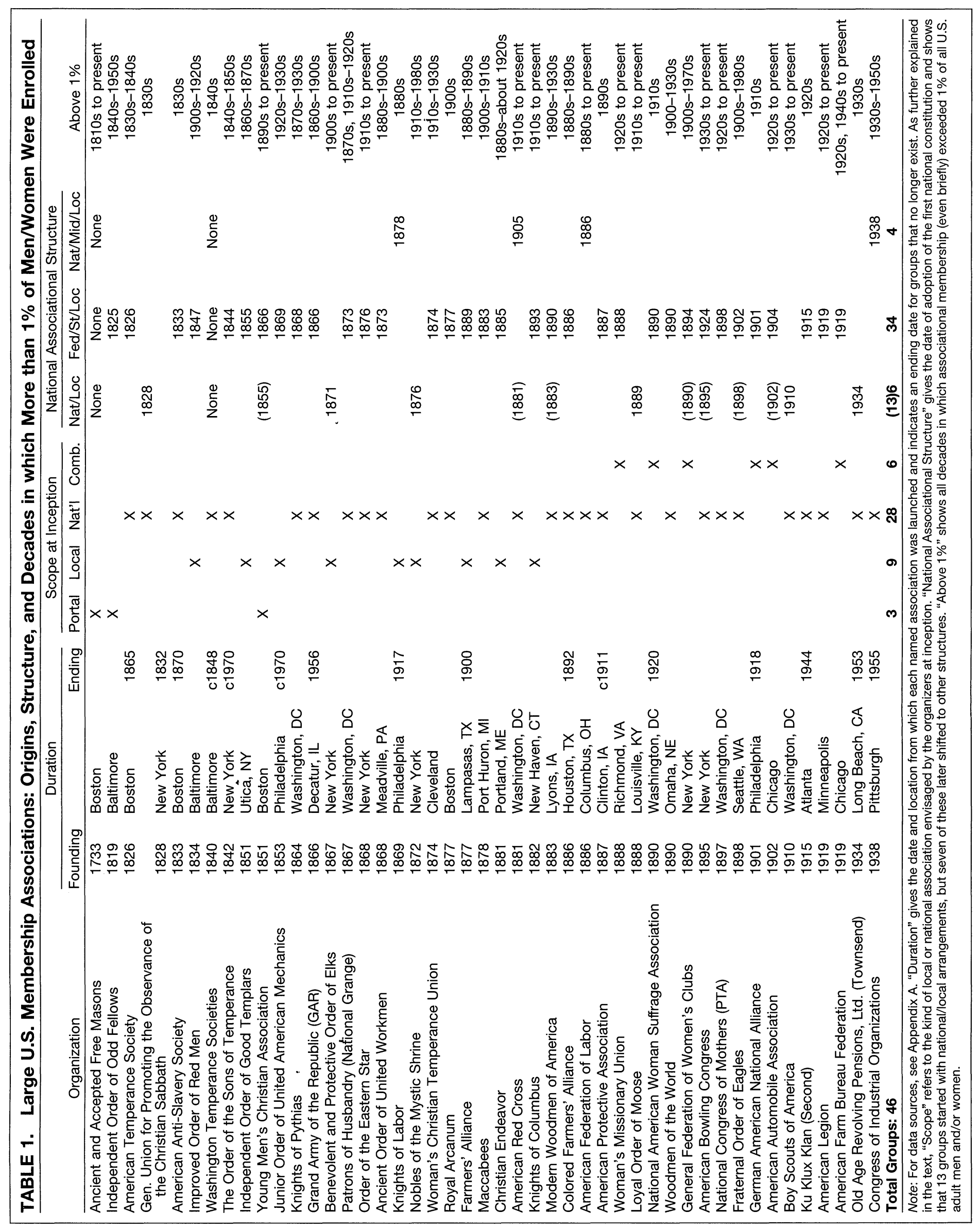


TABLE 2. Large U.S. Membership Associations: Intended Scope at Inception

\begin{tabular}{|c|c|c|c|c|c|}
\hline \multirow[b]{2}{*}{ Founding Era } & \multicolumn{4}{|c|}{ Intended Scope at Inception ${ }^{a}$} & \multirow[b]{2}{*}{$\begin{array}{c}\text { Total Large } \\
\text { Associations } \\
\text { Founded }\end{array}$} \\
\hline & $\begin{array}{l}\text { International } \\
\text { Portal }\end{array}$ & $\begin{array}{l}\text { Local: } \\
\text { Focused on } \\
\text { City or State }\end{array}$ & National & $\begin{array}{l}\text { Combination of } \\
\text { Existing } \\
\text { Groups }\end{array}$ & \\
\hline $\begin{array}{l}\text { Colonial period } \\
\text { (prior to 1790) }\end{array}$ & $1(100 \%)$ & $0(0)$ & $0(0)$ & $0(0)$ & 1 \\
\hline $\begin{array}{l}\text { Early national } \\
(1819-59)\end{array}$ & $2(20 \%)$ & $3(30)$ & $5(50)$ & $0(0)$ & 10 \\
\hline $\begin{array}{l}\text { Post-Civil War } \\
(1860-99)\end{array}$ & $0(0 \%)$ & $6(22)$ & $18(67)$ & $3(11)$ & 27 \\
\hline $\begin{array}{l}\text { Twentieth century } \\
(1900-40)\end{array}$ & $0(0 \%)$ & 0 & $5(62.5)$ & $3(37.5)$ & 8 \\
\hline Total & $3(6.5 \%)$ & $9(19.5)$ & $28(61)$ & $6(13)$ & 46 \\
\hline
\end{tabular}

even in tiny towns (Brown 1974; Mathews 1969). Early in the life of the fledgling republic, moreover, popularly rooted membership associations were organized on a national scale. They took shape at the critical sociopolitical juncture between the 1820 s and 1840 s, when voting rights were extended to most U.S. adult males and competing political parties (themselves federations of local and state organizations) emerged to mobilize the mass electorate (Aldrich 1995, chap. 5; Shefter 1994, 66-71). The American Temperance Society, the American Anti-Slavery Society, and the General Union for Promoting the Observance of the Christian Sabbath (GUPOCS, which agitated to close U.S. post offices on Sunday) all aimed for large size and geographical spread because their organizers wanted to change national mores and influence state and national legislation. These massive crusades appealed to-and helped stimulate - a democratically aroused citizenry (John 1995, chaps. 5-7; Tyler 1944, Part III).

In the same era, nonpolitical groups also moved toward national projects and institutions. Of these, by far the most important was the Independent Order of Odd Fellows, which was destined to become an organizational model and seedbed for hundreds of other membership federations. Odd Fellows were the next significant fraternalists after the Masons to enter the United States; the original ones were transplanted English workingmen who met regularly to perform the moral rituals and acts of mutual aid for neighbors and travelers that were the transnational stuff of fraternal life (Clawson 1989). But Oddfellowship in America soon shifted from a series of coastal outposts of English orders into a national project under the tellingly labeled leadership of Baltimore's "Washington Lodge No. 1," which hoped to connect preexisting Englishchartered lodges while simultaneously chartering new ones in America. The Baltimore Odd Fellows split into multiple organizational levels during the 1820 s, separating a "Grand Lodge of Maryland" from the original Washington Lodge, and then forming a new "Grand Lodge of the United States" juridically separate from the state-level unit (Independent Order of Odd Fel- lows [IOOF] 1844; Stillson 1897, Div. II, Sec. I and II). The leader in Baltimore, Thomas Ridgely, went on the road to persuade lodges in other states to join or form under the Maryland-centered jurisdiction. Potential recruits were made a very attractive offer: They could establish local and state lodges and send representatives to national meetings in Baltimore but would not be subordinated to the Marylanders.

American Odd Fellows fashioned a new structure that imitated and paralleled the U.S. constitutional order. As chronicler Henry Stillson (1897, 214) explains, immigrant members with "superior discernment" realized "the impracticality" and "especial unfitness for this country" of English-style governing arrangements (which coordinated local lodges through national committees of notables) and "found their model in the political framework of the United States." Probably the Marylanders led the way for much the same reason that small state representatives had been the first to ratify the 1789 U.S. Constitution: Representative federalism with state as well as a national "sovereign" jurisdictions afforded extra prestige and leverage to people from smaller states. Using their three institutional levels to outmaneuver New York City lodges, which harbored ambitions of their own, Baltimore Odd Fellows made themselves the founders of a new fraternal republic that broke from British allegiance to become America's Independent Order of Odd Fellows, whose new constitution unmistakably echoed the U.S. Constitution (IOOF 1844, xv):

Whereas, it has been found expedient, and of great importance to mankind, to perpetuate those institutions which confer on them great and essential benefit. Therefore, the GRAND LODGE OF THE UNITED STATES ..., for the more effectual purpose of binding each other in the bond of one common Union, by which we will be enabled to insure a co-operation of action, ... and to secure unto ourselves and posterity more effectually the blessings which are to be derived from so valuable and beneficial an institution, do ordain and establish the following as the CONSTITUTION... OF THE INDEPENDENT ORDER OF ODD FELLOWS. 
Similar representative federal institutions were soon adopted by many other brotherhoods, including America's first indigenously spawned fraternal organization, the Improved Order of Red Men, which evolved from a Baltimore-centered "tribe" into a three-tiered order (Lichtman 1901, chaps. 5-6). More telling, three-tiered arrangements were adopted by minority-ethnic orders, such as the Ancient Order of Hibernians, launched in 1836 (Ridge 1986); the German Order of Harugari, launched in 1847 (Stevens 1899, 234-5); and the Bohemian Slavonic Benevolent Society, started in 1854 and explicitly modeled after the Odd Fellows (Martinek 1985, 22). As new ethnic groups arrived in the United States, they formed associational edifices topped with national and state bodies even when there were barely enough members to form chapters scattered across a few large cities.

Organizational routines that included local membership meetings, standardized rituals, and the dispatch of elected officers and representatives to regular state and national governing conventions soon proved attractive to more than just fraternal groups. Early mass temperance associations, for example, went through a period of organizational experiments, some of which faltered (Dannenbaum 1984; Krout 1925). The American Temperance Society proved too top-down to sustain its popular appeal, and it evolved into a national center for publishing and lobbying (much like late-twentiethcentury American professional advocacy groups). The Washingtonian movement experimented during the 1840 s with radical, bottom-up democracy (much like 1960s-style New Leftists), only to find that loosely networked, entirely flexible local groups with few rules and no state or national governing structures could not sustain themselves beyond the initial popular fervor (Grosh 1842; Maxwell 1950). Thereafter, many Americans interested in "the temperance cause" flowed into the Sons of Temperance, founded in 1842, and the Independent Order of Good Templars (IOGT), founded in 1851, both of which achieved enduring new syntheses of moral fervor and representative federal organization. The Sons combined temperance advocacy with lodge rituals and the provision of social benefits (Hodges 1877); and the Good Templars adapted fraternal forms to America's first civic experiments with gender and racial inclusion, allowing women and African Americans to become members and serve as elected leaders (Fahey 1996).

If Schlesinger was right about early-nineteenth-century Americans converging on a model for large membership associations that paralleled governmental federalism, he was likewise correct that the Civil War brought a "heightened sense of nationality" to association-building. As Table 2 shows, associations that would manage to grow very large emerged at an accelerated rate starting in 1864, and most postwar foundings were nationally ambitious from the start. Half the eventually large groups founded between 1819 and 1859 were initially national projects, but in the late 1800 s more than two-thirds of such launchings were national projects. ${ }^{3}$ In the same era, hundreds of other nationally or regionally ambitious associations were also launched (Palmer 1944; Stevens 1899).

Following the Civil War, the national-state-local model diffused across various kinds of voluntary endeavors in addition to fraternal brotherhoods and sisterhoods. It was adopted by veterans' associations (from the Grand Army of the Republic to the American Legion); by independent women's groups (from the Woman's Christian Temperance Union, to the General Federation of Women's Clubs, to the National Congress of Mothers, which eventually became the modern PTA); by farmers' organizations (from the Grange, to the Farmers' Alliances, and ultimately the American Farm Bureau Federation); and by assorted moral and political crusades (including the YMCA, which added a state tier to its organizational structure in 1866, as well as Christian Endeavor, the American Protective Association, and the National American Woman Suffrage Association).

In one especially telling case, the Knights of Columbus, federalism hardly came easily. Founded in New Haven as a local Irish Catholic men's group, the Knights of Columbus was initially embedded in church parishes and dioceses and was closely supervised by Catholic clerics (Kaufman 1982, chaps. 1-4). As cognate groups emerged across Connecticut, they remained so embedded. But a deliberate switch to a local-state-national federated structure with elected lay leaders came in the late 1880 s and 1890 s, when leaders decided to take the Knights of Columbus national in competition with the Masonic Knights Templar and other Protestant-dominated fraternal associations. Pressures to compete and legitimize the undertaking drew the Knights of Columbus toward the governance model widely used by nationally ambitious associations of that time, even when "going federal" meant breaking from the original diocesan mold. The group also imitated the standard U.S. associational practice of electing lay officers, instead of having priests or bishops head its local, state, and national councils.

Overall, nearly three-quarters of the U.S. membership associations that grew very large before 1940 (34 of 46 groups) developed federated organizational arrangements that resembled the representative, threetiered institutions of U.S. government. As Table 1 indicates, 28 of these 34 adopted the federal-state-local form when they first established a national organization. Six others shifted from a national-local arrangement to the multitiered structure that included state units. Interestingly, several of the associations that moved away from center-local arrangements did so after members outside the founding center pressed for the addition of state units with significant authority. For example, the General Federation of Women's

\footnotetext{
${ }^{3}$ Many "national" federations incorporated modest numbers of members from English-speaking Canada, and sometimes people from Australasia and Europe as well. Although some of these were Americans living abroad, we do not count foreign-based members in deciding whether associations exceeded $1 \%$ of the U.S. adult population. Like Canadian baseball teams today, foreign chapters and members were incorporated into U.S.-centered institutions.
} 
Clubs was orchestrated by New York clubwomen, but women's groups in Maine and Utah spontaneously established their own state federations and pressed the national center to accept the new institutional level (Wells 1953, 34-7). Similarly, soon after the 1898 launching of the Fraternal Order of Eagles in Seattle, Washington, members in New York campaigned to establish state-level "aeries" (Fraternal Order of Eagles 1913; O’Reilly 1904, 77-81).

Among the membership associations in Table 1 that did not adopt the federal-state-local format, four groups (the Knights of Labor, Red Cross, American Federation of Labor, and Congress of Industrial Organizations) developed other kinds of multitiered arrangements; two others, the blue-lodge Masons and the Washingtonian temperance movement, never developed national centers. ${ }^{4}$ Of the 46 U.S. voluntary associations that attained very large memberships before 1940 , only six $(13 \%)$ were permanently institutionalized as center-local organizations. ${ }^{5} \mathrm{~A}$ representatively governed intermediate tier, usually at the state level, was overwhelmingly typical.

\section{Why Did National-State-Local Federalism Take Hold?}

Institutional theories (see Hall and Taylor 1996) allow us to go beyond Schlesinger in understanding why America's largest membership associations (and hundreds of smaller ones as well) adopted an organizational structure similar to the institutional arrangements of U.S. government. Two arguments are relevant: hypotheses about "political opportunity structures" and ideas about organizational imitation.

Social movements often organize to take advantage of opportunities for leverage offered by governmental institutions (Kitschelt 1986; Tarrow 1996b). From the beginning, the American political system rewarded movements and associations able to coordinate efforts at the national, state, and local level. From temperance and antislavery crusades, to farmers' groups, women's movements, and nativist agitations, groups aiming to shape public opinion and influence legislators learned the advantage of cross-level organization. By serving as a bridge between local sets of citizens and elected

\footnotetext{
4 State organizations are not entirely absent in these cases. Masons, of course, have strong state-level grand lodges. The Red Cross made brief attempts to set up state units before settling on a regional arrangement. State organizations with very weak representation at the national level are parts of the AFL (and AFL-CIO), although international unions have always been the key units in the labor federations.

5 Of these, GUPOCS was a short-lived movement of church-based groups and individual petition-signers; the Boy Scout troops and Townsend/Old Age Revolving Pensions groups were coordinated by corporate-style directorates. Center-local arrangements characterize the Elks, the Moose, and the Shriners, all of which evolved from interurban networks originally devoted to recreational activities. Interestingly, some years after the national foundings, factions within both the Moose and the Elks agitated for the establishment of state grand lodges. Such efforts did not succeed because the urban lodges did not want to give up their direct ties to the national center. Nevertheless, purely voluntary, nonsovereign state associations are allowed by both the Moose and the Elks.
}

officials, associations could influence both Congress and state legislatures (for instances, see Skocpol 1992, parts 1, 3). Operating across levels, moreover, groups could pursue social as well as political change. "Our Order," explained the Right Worthy Grand Templar of the Independent Order of Good Templars (IOGT) in 1881 (quoted in Turnbull 1901, 88-9), "is organized to destroy the evils growing out of the drink traffic, and the individual use of alcoholic drinks." Because the "drunkard-makers have strong Local, State, and $\mathrm{Na}$ tional Organizations," subordinate lodges reach out to save individuals and agitate public opinion, while "against the State Liquor Union" the IOGT arrays the state-level "Grand Lodge; and against the American Brewers' Congress and National Distillers Union" it deploys the national-level "R.W.G. Lodge."

But the response of activists to political opportunities and challenges is not a sufficient explanation, because many nonpolitical associations also adopted representative-federal arrangements. For the Odd Fellows, the Knights of Columbus, and other ritual or social associations, constitutional federalism was a way to coordinate activities across localities and regions. According to institutional theorists of organizational development (Powell and DiMaggio 1991), organization-builders who face complex challenges in conditions of uncertainty are inclined to copy well-understood, already legitimate models in their environment. Dynamic variants of sociological institutionalism (e.g., Clemens 1997) suggest that innovative adaptations of this sort are likely when ambitious but somewhat marginalized organizers (such as immigrants to America) confront unprecedented challenges or opportunities and are able to draw on a new "repertoire" of collective action. After the American Revolution, the U.S. Constitution offered a widely understood and prestigious model for cross-local coordination in an era when popular mobilization made sense for all kinds of purposes. Once some groups used this model successfully, others found it legitimating and competitively advantageous to follow suit.

Still, as the United States industrialized, representative-federal associations might have given way to classdivided or corporate-style associations paralleling the emergent national market economy. But a cataclysmic and pivotal political event, the U.S. Civil War, intervened to reinforce the legitimacy and practicality of popularly rooted federalism as the preeminent model for large-scale association-building. The United States in 1860 had little in the way of a standing army, so both sides in this internecine struggle relied upon civilian as well as elected leaders to assemble local volunteers into state units, and then to mold state units into the clashing armies and civilian relief organizations of the Union and the Confederacy (Brockett 1864; McPherson 1988, chap. 10). After the war ended, spirits soared on the winning Union side. Inspired by a new sense of national purpose and thoroughly familiar with federal models of popular mobilization, northern men and women who grew to maturity in the late $1800 \mathrm{~s}$ launched many new mass-based federations, even as 
electoral mobilization by clashing party federations also reached its peak (McGerr 1986).

Qualitative evidence suggests ways in which Union mobilization encouraged postwar association-building. Railroad workers who met during the Civil War launched the Ancient Order of United Workmen from Meadville, Pennsylvania, in 1868, aiming to bridge class divisions and offer insurance and cultural uplift to all American working men (Upchurch 1887). America's third largest fraternal association, the Knights of Pythias, was founded in Washington, D.C., in 1864 by young clerks who met in the wartime civil service and devised a ritual of sacrificial brotherhood that appealed not only to former soldiers but also to all Americans who hoped to reknit North and South (Carnahan 1890, chaps. 5-6). Another regionally disparate group of federal clerks started the Patrons of Husbandry (or Grange) in 1867. This happened after Minnesota native and federal agriculture official Oliver Kelley was commissioned by President Andrew Johnson to assess rural needs in the devastated South (Nordin 1974, chap. 1). Using Masonic ties to make contacts in the defeated region, Kelley soon realized that farmers, too, could benefit from a nationwide fraternity. With fellow officials-each of whom, like him, moved back and forth between Washington and his home regionKelley designed a federation that incorporated some existing farm groups and stimulated the founding of thousands of local granges.

The Civil War also emboldened civicly minded women. Along with the famous wartime nurse Clara Barton, many other women and men who had been active in the wartime U.S. Sanitary Commission agitated from the 1860 s to 1881 for congressional charter of the American Red Cross (Davidson 1950b). Meanwhile, females moved to the fore in the massive temperance movement. Willing to accept women leaders and members on equal terms, the IOGT held its own during the war and burgeoned afterward, prodding the Sons of Temperance to accept females. But American women wanted an even more predominant role. Determined to counter male drunkenness, which had been exacerbated by military service, and fight government policies favorable to the liquor industry, which had become a lucrative source of tax revenues during the war, reformers convened in Cleveland, Ohio, in 1874 to launch the Woman's Christian Temperance Union (WCTU). Some of these women had met in Union relief efforts; all of them applauded the women's crusades against saloon-keepers that spread in the Midwest during the early 1870s (Mezvinsky 1959). Grassroots protests were hard to sustain, however, so women gathered at a summer camp for the National Sunday School Assembly to institutionalize "the grand temperance uprising." In cadences resonant with the "Onward Christian Soldiers" rhetoric of Union victory, a "Committee of Organization ... consisting of one lady from each state" issued a "Call" to organize the national WCTU (reprinted in Tyler 1949, 18). "In union and in organization," proclaimed the Call, "are ... success and permanence, and the conse- quent redemption of this land from the curse of intemperance."

\section{NATIONAL FEDERATIONS AND LOCAL GROUPS}

Although translocal voluntary federations may have emerged early in U.S. history and proliferated after the Civil War, it is possible that local groups weighed much heavier in community life. And perhaps chapters of large federations often proved short-lived, as social capital theory might predict, leaving the ground to be tilled by purely local joiners and organizers. To evaluate these possibilities, we need data on characteristics of local groups.

\section{Membership Groups in City Directories}

Gamm and Putnam $(1999,524)$ show that voluntary groups listed in U.S. city directories peaked in relation to population around 1910. What kinds of groups were these? To find out, we analyzed listings for 1910 (or the closest year available) for the same 26 cities from every region studied by Gamm and Putnam. ${ }^{6}$ In Table 3, cities are arrayed from top to bottom according to their size in the 1910 Census, and their groups are classified into structural categories. We count as "federated" several kinds of translocally linked groups: churches, unions, chapters of very large U.S. federations (listed in Table 1), and chapters of smaller federations. We tally as "nonfederated" all membership groups, including church-linked sodalities, that were not clearly part of separately organized translocal federations.

Had we eliminated local units affiliated with translocal associations (as in Putnam 1993), we would have missed most of the groups tallied in Table 3 . In every city, most of the groups listed in the directories were part of regional or national federations, ranging from a minimum of $63 \%$ in Boston to a maximum of $94.5 \%$ in Rome, Georgia. Local groups not so connected were slightly more prevalent in the larger cities, whereas groups in the smallest cities were overwhelmingly federated. Looking more closely, we see that, in addition to churches, very large membership associations were at the very heart of American civil society locally as well as nationally. Churches and other religious congregations, devoted to translocal world views and linked to federated institutions of various sorts, were numerous in every city. Equally prevalent were local chapters of large membership federations listed in Table 1. And most "unions" were linked to the American Federation of Labor or the Knights of Labor.

From $8 \%$ to $29 \%$ of groups in these cities were local chapters of federations other than the very largest. These smaller federations, which ranged from ethnic

\footnotetext{
${ }^{6}$ We are grateful to Gamm and Putnam for giving us copies of some of the directories they used. In most cases, we obtained copies from libraries or historical societies in the respective cities or used microfilms in the extensive collection of city directories held by the Boston Public Library. These copies were either for the same years or within one year of directories used by Gamm and Putnam (1999, Appendix A).
} 


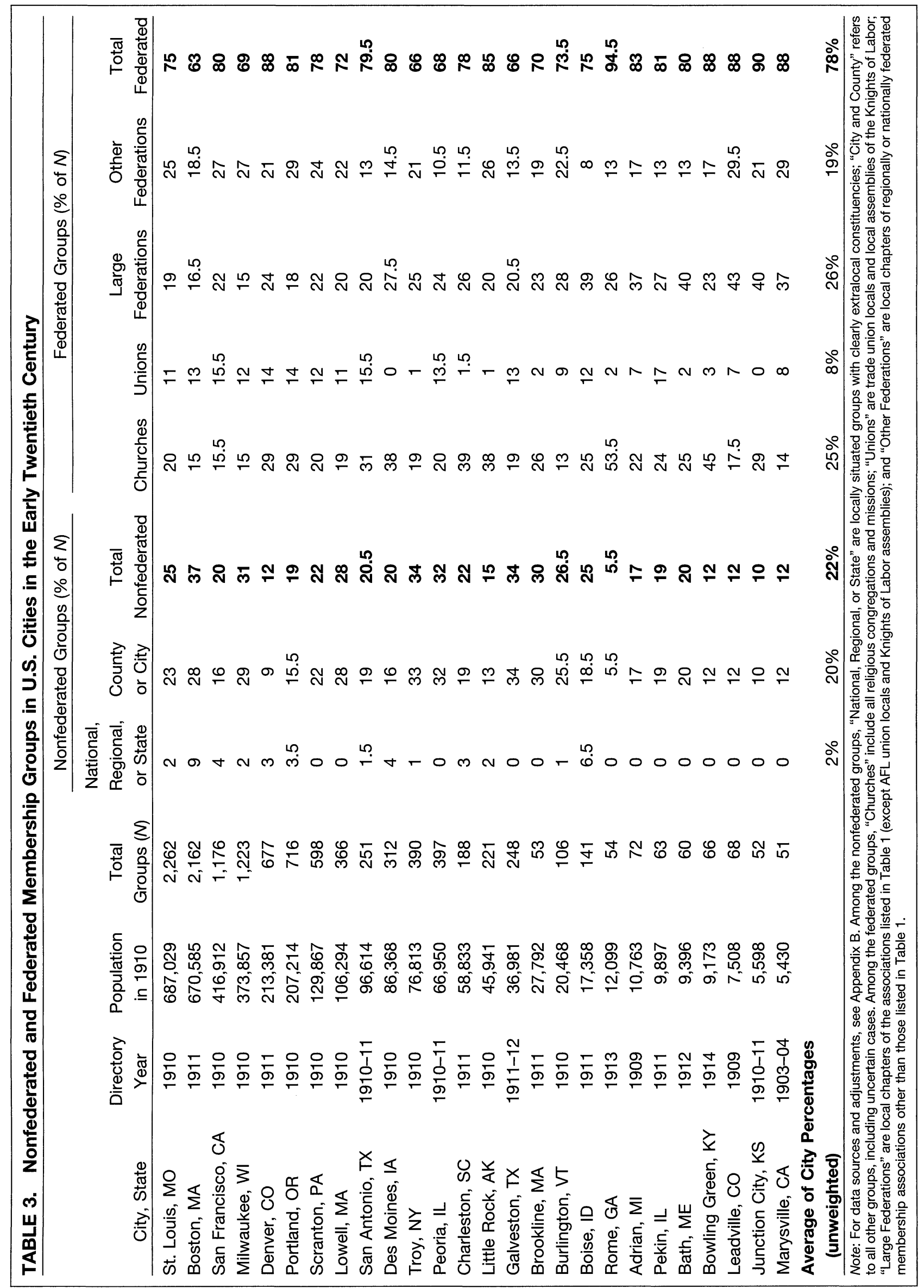


TABLE 4. The Stability of Membership Associations in U.S. Cities, 1890-1920

\begin{tabular}{|c|c|c|c|c|c|c|}
\hline \multirow[b]{2}{*}{ City, State (Directory Years) } & \multicolumn{6}{|c|}{ Percent in Three Consecutive Directories, or Last Two } \\
\hline & $\begin{array}{l}\text { All } \\
\text { Groups }\end{array}$ & Churches & $\begin{array}{c}\text { Large } \\
\text { Federations }\end{array}$ & $\begin{array}{c}\text { Other } \\
\text { Federations }\end{array}$ & Unions & Local \\
\hline $\begin{array}{l}\text { Adrian, Michigan } \\
\quad(1890-91 ; 1900-01 ; 1909 ; 1921)\end{array}$ & 38 & 83 & 48 & 13 & 33 & 7 \\
\hline $\begin{array}{l}\text { Bath, Maine } \\
\quad(1892 ; 1900-01 ; 1912 ; 1919-20)\end{array}$ & 51 & 88 & 61 & 40 & 0 & 24 \\
\hline $\begin{array}{l}\text { Boise, Idaho } \\
\quad(1891 ; 1901-02 ; 1911 ; 1921)\end{array}$ & 43 & 62 & 57 & 38 & 43 & 9 \\
\hline $\begin{array}{l}\text { Brookline, Mass. } \\
\quad(1891 ; 1901 ; 1911 ; 1920)\end{array}$ & 42 & 78 & 43 & 22 & 0 & 38 \\
\hline $\begin{array}{l}\text { Burlington, Vermont } \\
\quad(1890 ; 1900 ; 1910 ; 1920)\end{array}$ & 40 & 76 & 66 & 34 & 43 & 19 \\
\hline $\begin{array}{l}\text { Leadville, Colorado } \\
\quad(1890 ; 1902 ; 1909 ; 1918)\end{array}$ & 53 & 100 & 64 & 41 & 32 & 36 \\
\hline $\begin{array}{l}\text { Pekin, Illinois } \\
\quad(1893 ; 1900-02 ; 1911 ; 1921)\end{array}$ & 53 & 100 & 67 & 33 & 42 & 37 \\
\hline $\begin{array}{l}\text { Rome, Georgia } \\
\qquad(1888 ; 1898-99 ; 1913 ; 1919)\end{array}$ & 43 & 45 & 70 & 21 & 0 & 0 \\
\hline $\begin{array}{l}\text { Average of city percentages } \\
\text { (unweighted) }\end{array}$ & $45 \%$ & $79 \%$ & $60 \%$ & $30 \%$ & $24 \%$ & $19 \%$ \\
\hline
\end{tabular}

and insurance-oriented fraternal groups to nativist, patriotic, and service associations, were organized and functioned in ways similar to the large associations listed in Table 1. They held regular local meetings and supralocal conventions, and they deployed organizers and members to spread their message and establish chapters on a regional if not national scale.

Local groups not obviously linked to broader federations ranged from 5.5\% of directory entries in Rome, Georgia, to $37 \%$ of entries for Boston. But some of these groups clearly had constituencies that transcended city boundaries. Large cities (like Boston) hosted headquarters for national or regional associations; smaller cities (like Boise, the largest in Idaho) sometimes served as associational centers for their state or region. In the final analysis, only a minority of the groups listed in each city directory $(22 \%$ was the average across 26 sites) was specific to that city or county. ${ }^{7}$ Many of these were business or professional associations or elite clubs of one sort or another, which are hardly prime venues of democratic engagement. Choral groups, mutual aid societies, shurch sodalities, orchestras and bands, and sports and recreational clubs - the sorts of purely local, popular groups Putnam (1993, 91-2) considers typical of civic Americaaccounted for only a tiny fraction of groups in these

\footnotetext{
${ }_{7}$ The average percentages presented in Table 3 are not weighted by the relative number of groups in different cities. Because larger cities (especially Boston) had somewhat more headquarters and local groups, "nonfederated groups" are $26 \%$ of all groups summed across all cities.
}

cities. In classic U.S. associational life, most popularly rooted groups were parts of translocal federations. ${ }^{8}$

\section{Persistence and Volatility}

Although the cross-sectional tallies in Table 3 reveal large proportions of federated groups, perhaps translocally linked churches, unions, and chapters were too short-lived to have much civic significance. To find out, we explored group stability. Analysis was done by hand by a knowledgeable coder, and issues of consistent coverage across directories had to be resolved (see Appendix B). We examined groups in eight regionally dispersed small cities, and we focused on similar times (circa 1890, 1900,1910, and 1920) in order to control as much as possible for nationwide associational trends. ${ }^{9}$ In each city, we traced named groups (such as "Beacon Street Methodist Church" or "Maple City Camp No. 2884" of the Modern Woodmen). Groups are classified as relatively stable if they appear in three or more consecutive directories or in the last two.

As Table 4 shows, religious congregations were extraordinarily stable in these cities (with the partial exception of Rome, Georgia, which had a dispropor-

\footnotetext{
8 Were purely local groups more prevalent in decades before 1910 ? Examination of directories back to the 1870s suggests that federated groups were proportionately even more prevalent in earlier decades. ${ }^{9}$ We used all except three of Gamm and Putnam's (1999) eleven small cities; the others were set aside because directories with comparable coverage were not available at times close to the decade intervals.
} 
tionately large number of churches, including some volatile white and African American Baptist congregations). Local chapters of America's largest voluntary federations (apart from AFL unions and the Knights of Labor) were also quite stable. In contrast, nonfederated local groups were not very persistent, contrary to what social capital theory suggests.

Among federated groups, unions were markedly less stable than churches and chapters of large membership federations. Part of the reason may be that labor groups were not consistently included by compilers of city directories. But when labor groups were listed, they often appeared at just one decade point, because they rose or fell in response to industrial struggles and economic booms and busts. For example, unions and Knights of Labor assemblies disappeared following the defeat of strikes in Leadville, Colorado, and unions multiplied temporarily during the ship-building boom in Bath, Maine, during World War I.

In six of the eight small cities, units of translocal federations other than the very largest were more persistent than nonfederated local groups, but in all eight cities such smaller federated units were much less persistent than chapters of the largest federations. The era between 1880 and 1920 witnessed the rise and demise of hundreds of insurance-providing fraternal associations (such as the Order of the Iron Hall and the Knights and Ladies of the Fireside), the vast majority of which remained modest in membership. Many of these groups soon proved economically insolvent, and the more successful ones tended to merge or turn into insurance companies after 1910.

Churches and local units of the largest voluntary federations proved the most persistent. The average of city percentages in Table 4 shows this, and another calculation documents the same point. Adding together all 450 groups that were relatively stable across these eight cities between 1890 and 1920, we find that $31 \%$ were religious congregations and another $38 \%$ were clubs or lodges connected to the largest crossclass national federations. Thus, more than two-thirds of all stable groups fell into these categories. Once founded, churches and chapters linked to the largest federations took firm root and became the enduring core of civil society in modernizing America.

Chapters of major federations flourished in part because national and state leaders in such vast civic republics as the Odd Fellows, the Grand Army of the Republic, and the WCTU assumed responsibility for sustaining as well as initiating local chapters. Reports of annual or biennial meetings describe all the steps taken by elected officers-and the many miles they traveled-to shepherd their flocks. "To enhance their reputation for sound leadership, supralocal officers not only offered inspiration and programmatic suggestions but also fostered connections among chapters in their orbit. When a local club or lodge ran into trouble, moreover, supralocal leaders could make a real difference, especially in the larger, well-established federations. They might ask neighboring chapters to support faltering units (as in the "Big Brother Aerie" program mounted by the Fraternal Order of Eagles). During economic downturns, national or state officials might forgive shares of local dues; when meeting houses burned down, they orchestrated appeals for aid. Support from above could sustain locals of major federations, whereas disconnected groups or the chapters of weak federations often faltered.

\section{VOLUNTARY FEDERATIONS IN A NATION ON THE MOVE}

Because large membership federations were central to local communities as well as the nation, we need to know more about how they developed. As a first step, we can dissect the growth of very large membership federations with units at the state level as well as the local and national levels. How were such federations assembled?

We can readily imagine a pattern in which, after national organizers declare a new project, local groups spread and memberships swell; only later do state-level units emerge. In fact, a very different dynamic usually prevailed, namely, an encompassing network of statelevel units formed very early in the life of expanding federations. To illustrate this point, figures 1 and 2 display the slopes of membership growth and local and state organizational trends for the Knights of Pythias, a giant fraternal group that grew from a national project launched at the end of the Civil War, and for the General Federation of Women's Clubs (GFWC), which formed in 1890 as a combination of city groups. Despite disparate origins, both the Knights and the GFWC became institutionalized across many states well before their memberships burgeoned and before most local units were established.

These instances are not atypical. Figure 3 analyzes the relationship of membership growth and cross-state institutionalization for 30 of the 34 federal-state-local groups listed in Table 1 (Appendix A discusses the four omissions). This figure documents a strong relationship between the timing of recruitment of at least $1 \%$ of men and/or women and the timing of institutionalization in at least $60 \%$ of then-existing states and territories. ${ }^{10}$ Extensive institutionalization and large membership growth often occurred around the same time: Half the groups in Figure 3 are on or very close to the diagonal. Yet, the figure clearly shows that 11 of 30 groups $(37 \%)$ established institutions spanning at least $60 \%$ of states before recruiting $1 \%$ of adults into membership, even though this was quite an organizational feat at a time when new states and organized territories were joining the nation in thinly populated regions. For example, the WCTU is situated well below the diagonal in Figure 3; it had established "unions" in $60 \%$ of states and territories by the early 1880 s, considerably before it had enrolled $1 \%$ of women (in the late 1910s). ${ }^{11}$ Only three groups appear far above

${ }_{10}$ We also examined charts with higher thresholds of state organization. Raising the bar to $70 \%$ or $75 \%$ causes data points to crowd toward the diagonal but does not change the underlying patterns reported here.

11 The founding of a state unit was a significant marker of associa- 


\section{FIGURE 1. The Development of the Knights of Pythias, 1864-1940}

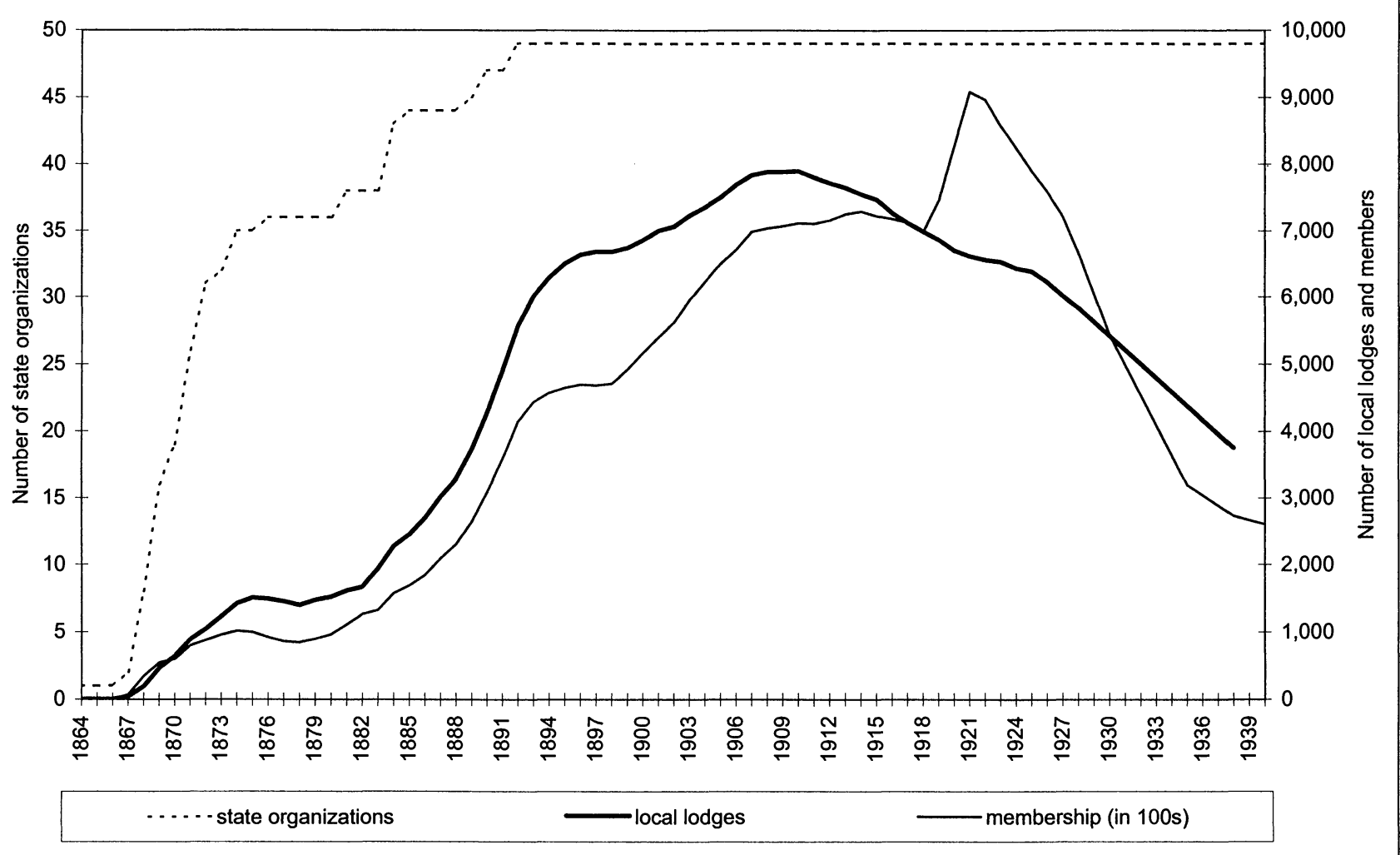

the diagonal in Figure 3, and two of these are only partially exceptional. The Woman's Missionary Union established state units across the South before recruiting its initial membership there; later, it added members in other regions before completing a nationwide state network. Starting from the West, the Fraternal Order of Eagles followed a similar pattern. Both federations began by spreading a wide cross-state institutional network within their home regions.

The fact that a wide network of state organizations was usually institutionalized before, or along with, the growth of substantial membership is strong evidence that intermediate as well as national institutions were important to the growth of U.S. voluntarism. Intermediate units were not just after-the-fact window-dressing for American voluntary federations. But what could supralocal institutions-national or intermediatepossibly contribute in an era when voluntary groups depended on the willingness of many ordinary men and women to attend meetings regularly and pay dues? To prosper, almost all classic American voluntary federations had to sink strong roots in localcommunities and neighborhoods. How could apparently elaborate and top-heavy federal arrangements, replete with offices, paid organizers, and subsidized travel for elected leaders, possibly have aided that process?

We theorize that federal frameworks sustained na-

tional presence. Rules varied among federations, but from five to twelve local chapters normally had to be established in the state or territory before leaders could apply to the national center to "charter" a sovereign and representative state organization. tionwide leadership networks and provided career lines, resources, and incentives for membership organizers. In the modernizing United States, nationally ambitious civic leaders had to spread ideas and recruit members in many places across a vast continent. Associational founders, such as Thomas Wildey of the Odd Fellows and Frances Willard of the WCTU, were constantly on the move, visiting as many locations as possible. Inspiring and effective, they seeded new groups wherever they went (on Wildey, see Stillson 1897, Div. II and III; on Willard, see Bordin 1986, chap. 8). Even so, hundreds to thousands of intermediate leaders had to do most of the work. Only they could tap into indigenous social networks and spread an association's ideals and models into every city and town, casting the net of membership and organization farther and farther afield. In turn, intermediate leaders had to be able to claim credit, coordinate activities, and gain access to portions of local dues. It made sense for national association-builders to foster, as soon as possible, intermediate institutions through which further organizing could proceed.

Embodying shared ideals and standardized associational routines, higher level leaders and institutional centers mattered precisely because the modernizing United States was so geographically and socially dynamic. Nineteenth-century Americans were constantly on the move, especially young men looking for work and entrepreneurial opportunities (Chudacoff 1972; Kopf 1977); indeed, interstate mobility rates reached an all-time peak in the mid-1800s (Hall and Ruggles 


\section{FIGURE 2. The Development of the General Federation of Women's Clubs, 1890-1940}

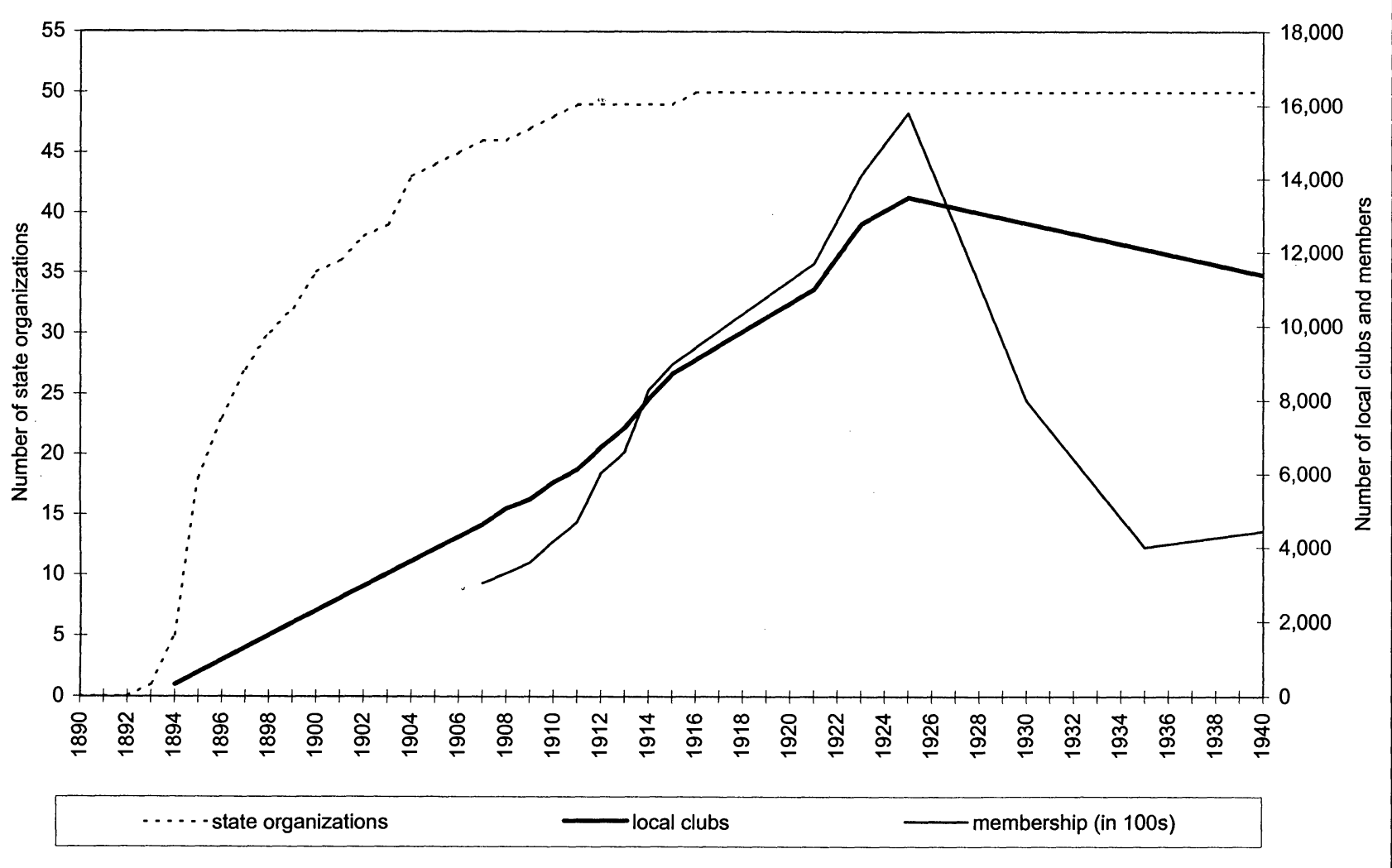

1999). As the United States expanded, translocally organized associations were very appealing (Berthoff 1971, chap. 27). People arriving in new places looked for familiar group meetings; members arranged "traveling cards" or introductions from native lodges or clubs to allow them admittance to cognate units elsewhere. Furthermore, if the new places did not already have familiar groups, authoritative supralocal centers and widely shared knowledge of standardized associational routines allowed members to become instant civic organizers. Strangers who shared the bond of membership in a nationwide association could coordinate their efforts, and local activists could contact leaders at higher levels for guidance and reinforcement. Based on primary testimonies, scenarios such as the following played out again and again. Each excerpt reveals notable feats of collective action by mobile Americans aided by national and state institutional centers and a translocal network of leaders.

The first Odd Fellows' lodge established in the Western Mississippi valley was Travellers' Rest Lodge, No. 1, in the city of St. Louis, for which a charter was granted by the Grand Lodge of the United States on the 18th of August, 1834 ... St. Louis was then an insignificant frontier town, with about 7000 inhabitants. There were seven petitioners for this lodge "made up" of transient members then in and about the city: one from England; two from Kentucky; three from Pennsylvania; and one from Maryland. By the time the lodge was instituted all but one of the original signers of the petition had disappeared and others had to be substituted.... Samuel L. Miller of Harmony Lodge,
No. 3, of Baltimore, who was about to remove to Alton, Illinois, was commissioned [by the U.S. Grand Lodge in Maryland] to institute the lodge.... At the close of the first year the lodge had 115 members" (reported in Stillson 1897, 355).

Being an account of the introduction of the Order of Knights of Pythias in the Grand Domain of Minnesota by ... David Royal who has been a continuous member of Minneapolis Lodge No. 1 for 27 years. In November 1868 I joined Wilmington Lodge No. 2 Wilmington Delaware. In the spring of ' 69 I arrived in this City [Minneapolis] and shortly after was employed as car builder for the C.M. \& St. Paul Railways at their Shops in this City. In the winter of ' $69-70$ I talked up Pythianism among the workmen and soon had a list of 13 names. I opened up correspondence with Supreme Chancelor Read who sent me some Blank applications for a dispensation [to open a lodge] and full instructions how to procede. About the first of June I received a letter from Supreme Chancelor Read stating that Bro[ther] Jacob H. Heisser of Marrion Lodge No. 1 of Indianapolis Ind had recently arrived in Minneapolis and had also written him about starting a Lodge. I was requested to drop Bro Heisser a line through the Post office and unite our efforts which request was complied with....

Saturday evening June 251870 a preliminary meeting was called [to apply for a charter].... I was chosen President and Bro Heisser [who had recruited two potential members was chosen] Secretary.... Supreme Chancellor Read arrived July 9th $1870 \ldots$... At Odd Fellows Hall Minneapolis Minn July 111870 agreeable to a call of the Supreme Chancelor of the Knights of Pythias Samuel Read of New Jersey a number of Knights and Citizens of 
FIGURE 3. Membership Growth and Institutionalization of State Units in Large U.S. Membership Federations

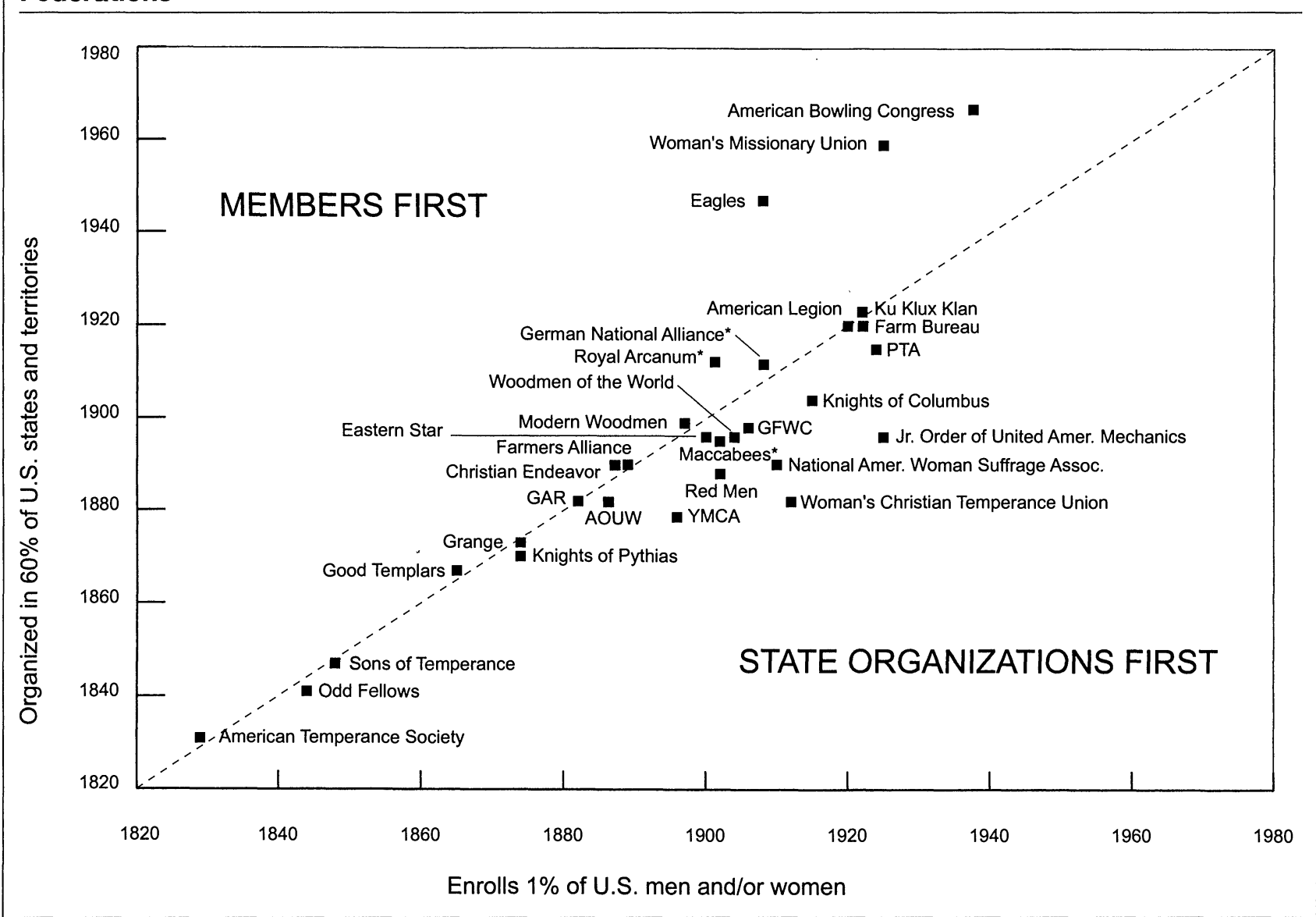

Note: Includes most federal-state-local groups from Table 1. Asterisks indicate parameters estimated with known limits. See Appendix A for sources and discussion of omitted groups and full names of organizations.

Minneapolis and vicinity assembled for the purpose of organizing a Lodge of, the Order (Royal [1890s] n.d.).

There are now [in the 1890s] seventy [women's] clubs in the Nebraska State Federation, and applications for membership constantly arriving. ... To fully understand what State federation has done, it is well to consider that more than two-thirds of the clubs now auxiliary to it were coexistent with it, and would never have been formed at all but for the permanence of organization and the wider range of thought which union with it and the General Federation promised. In one town of about fifteen hundred inhabitants there had been no literary organization of any kind for ten years previous to this movement. The same is true of many other towns on these prairies, each with its quotient of intelligent, well-educated people, transplanted from the cultured atmosphere of the older States, who had become discouraged by the difficulties of their environment, but who are now developing State pride, and are enthusiastically alive to all the privileges of federated clubs (reported in Croly 1898, 779).

National and intermediate institutions, representatively governed, helped the modernizing United States become a nation of associational organizers as well as a collection of potential joiners. Supralocal centers provided resources and created incentives for leaders to reach out and help establish new local units, even as these same centers continued to link and inspire the efforts of established chapters. Nationally standardized and shared institutional models also made it possible for every associational member to become an organizer, should need or opportunity arise (as it did for David Royal and Jacob Heisser after they arrived separately in Minneapolis). Supralocal institutions were anything but irrelevant or oppressive bureaucratic overhead. By making it easier for Americans to "combine," even when (actual or potential) "brothers" and "sisters" did not previously know one another personally, these arrangements furthered associational vitality in an expanding and mobile nation. Disparate local groups bubbling up sporadically and informally from below could never, we submit, have achieved the same widespread and stable civic results.

\section{RECONCEPTUALIZING CIVIC VITALITY IN AMERICA AND BEYOND}

Our findings reveal the theoretical as well as empirical weaknesses of localist arguments about the roots of American civic voluntarism. Drawing on social 
capital ideas, for example, Gamm and Putnam (1999, 551), hypothesize that small American cities were associationally prolific around 1900 because they were more socially enclosed than large metropolises. In fact, cities of all sizes in modernizing America were well connected to one another and to rural hinterlands, and voluntary groups in communities of all sizes were usually part of the same nation-spanning voluntary federations. Indeed, groups located in the smallest cities were the most federated of all. This makes sense because associational organizers tried to spread their network into even very small places, and because Americans on the move wanted to found or join familiar groups near home or work. In the apt words of the quotation regarding the Nebraska State Federation of Women's Clubs, federated chapters linked their participants to "the permanence of organization and wider range of thought ... promised" by "union with" representative state and national associational centers. Classic American voluntary associations were not at all expressions of geographically bounded social enclosure. ${ }^{12}$ Multitiered national federations were the key institutional supports of classic American voluntarism because they simultaneously sustained intimate solidarities and connections to wider worlds.

Although often discussed as either top-down or bottom-up creations, classic U.S. membership federations were actually a well-institutionalized combination of both processes. Supralocal leaders articulated shared goals, world views, and identities, even as they spread organizational models and helped local chapters organize, persist, and pursue varied activities. Authoritative federations were effective holding environments for civic life. But they were not bureaucratic because they operated on representative principles and relied on the willingness of ordinary people to join local chapters, attend meetings, pay dues, and elect conscientious officers. Local chapters channeled indispensable resources of money and human energy to the "higher" levels of federations. Constructed as intricate combinations of organizational authority and member engagement, America's great voluntary federations could help geographically mobile citizens create, coordinate, and sustain local voluntary groups as well as simultaneously generate sufficient clout to affect politics or societal mores beyond as well as within local communities. An example such as the Ku Klux Klan

\footnotetext{
12 Of course, many classic federations were gender-specific, racially exclusive, and centered on Protestants. Yet, it is important to underline the surprising inclusiveness of some of the largest or most influential voluntary federations, even apart from labor groups. African Americans were at least partially included in the IOGT, the WCTU, and the military veterans' associations; women participated along with men in the IOGT and the Grange. American women also ran many of their own great federations, long before the modern feminist era. Although not willing to accept African Americans, a number of the largest fraternals did include Jewish lodges as well as ethnic-identified lodges that were allowed to conduct activities in many European languages. Surprisingly, the early Odd Fellows allowed Spanish-speaking lodges in Florida (see Stillson 1897, 331). What is more, most classic voluntary federations brought together people from various occupations and classes, a form of inclusiveness arguably not often found in U.S. associations today.
}

shows that federated associations did not always weigh in on the side of the good. And they did not always hold together or grow very large; like the early United States itself, many broke apart in internecine battles. But voluntary federations that successfully managed their internal conflicts could recruit large numbers of members and exert great influence in national as well as local American life.

Our research not only substantiates an institutional and translocal conception of American voluntarism it also suggests that government and politics need to be integrated into research on the formation of civil societies. Commentators often assert that early Americans created and relied on purely local voluntary groups because the pre-New Deal state was too weak to accomplish collective tasks. This standard wisdom neither notices nor explains the development of nationally federated membership associations that so closely mirrored the representative and federal arrangements of U.S. government and proliferated in close relationship to key episodes of nation-state formation.

The American state was not the sort of bulky, authoritarian bureaucracy whose deleterious effects on civil society Alexis de Tocqueville feared. From the start, U.S. constitutional government was nevertheless pervasive and effective in many ways. The Bill of Rights broke the unity of state and church authority, which allowed citizen-run associations to compete freely with one another and with a plurality of evangelizing churches (Brown 1974; Mathews 1969). The U.S. Congress developed the world's most efficient postal service and a system of postal and transportation subsidies that allowed places far from the Eastern seaboard to become full participants in national life (John 1995). The U.S. state thus furthered both coordination and competition, even as it afforded opportunities for political leverage at the local, state, and national level. What is more, popular struggles to create and preserve the U.S. state taught Americans to use constitutions and representative-federal organizations in many kinds of associational endeavors. Modeling their efforts on those used in political and military mobilizations, civic organizers in the developing American republic assembled voluntary membership federations that tied leader-organizers to one another and linked local groups to larger undertakings.

Emergent U.S. national institutions afforded unique opportunities for citizen-run voluntary federations - in the space between competing, nonofficial churches, on the one hand, and representative government, on the other. Significantly, both translocal voluntary federations and mass political parties took shape in the United States well before national corporations emerged to dominate the market economy. Early in the modernization process, American association-builders synthesized routines borrowed from representative government with world views borrowed from religion (usually ideas blended from Protestant denominations). Remarkably, U.S. voluntary associations achieved this synthesis of representative governance and moral purpose without becoming captives of either church or state. In many complex societies, voluntary 
groups have been controlled by powerful states or religious hierarchies, but in America lay citizens took charge.

\section{CIVIC AMERICA FROM PAST TO PRESENT}

We have focused on the emergence and initial spread of popularly rooted U.S. membership federations. A more complete overview would note the struggles experienced by almost all dues-based federations during the Great Depression and would highlight the symbiotic partnerships between the federal government and large voluntary federations that helped the nation mobilize for World War I and II, culminating in remarkable voluntary membership spurts after each great conflict. Although particular groups rose and fell, chapter-based federations of the sort that first took shape between the mid-1800s and the 1920 s continued to underpin U.S. civil society through the first twothirds of the twentieth century (Skocpol et al. 1999). Only after the mid-1960s did membership federations in general experience sharp decline, as new social movements and professionally run advocacy associations transformed civic life in unprecedented ways.

Today, many Americans are so disillusioned with national government and politics-indeed, with all authoritative institutions-that they are prepared to picture "Tocqueville's America" as a collection of spontaneous local efforts detached from government and politics. Similarly, many who worry that the United States is no longer a nation of voters and joiners hope that civic revitalization can occur apolitically and from the bottom up: Perhaps citizens can redress the nation's ills while organizing children's soccer games; perhaps foundations can solve national problems by dribbling tax-exempt grants to local community groups. But a more accurate picture of America's past suggests the need to think in new ways about contemporary civic dilemmas.

If the United States originally became a civic nation because translocal federations grew parallel to the institutions of national republican government, then Americans today need to worry about the decline of representative democracy as an arena and positive model for associational life. And if classic American membership groups were not just scattered local creations, but were linked into well-institutionalized national networks that used membership dues to support elected leaders who had authority and incentive to organize large numbers of fellow citizens, then perhaps revitalization of American civic life today will take more than efforts by self-appointed professional advocates operating out of Washington, D.C., or New York City, and more than the disconnected efforts of small groups operating apart from national politics and translocal movements. Perhaps the best aspects of America's civic past are not being perpetuated or replaced in today's civic world, where market models are displacing representative arrangements, and where civic leadership no longer entails popular mobilization or the organization of interactive associations. ${ }^{13}$

An institutional approach to civic life suggests that state, politics, and society are-for better or worseinevitably intertwined. From this perspective, the key to civic health lies not in local face-to-face interactions alone but in the nature of connections between powerful supralocal institutions and local or particular endeavors (for further arguments to this effect, see Berman 1997; Eckstein 1961; Evans 1997; Foley and Edwards 1999; Tarrow 1996a). Democratic accountability and balances of power are also critical, for "when bad men combine, the good must associate, else they will fail, one by one, an unpitied sacrifice in a contemptible struggle" (Knights of Labor of North America 1883, title page). Institutional and power realities shaped America's rich civic heritage, and they remain relevant today. Consequently, Americans who better understand their civic past may need to reimagine their democratic future and look to revitalize shared and representative institutions not just in national politics but in associational life as well.

\section{APPENDIX A: DATA ABOUT LARGE U.S. MEMBERSHIP ASSOCIATIONS}

Multiple primary and secondary sources were used to understand the origins and organizational arrangements of each large U.S. voluntary association listed in Table 1 . In addition to the scholarly studies and official associational histories listed below, we examined groups' constitutions, which are listed separately only when they establish points not documented elsewhere. For figures 1-3, the dates for state foundings and national membership and chapter trends in most cases were determined from associational records or convention proceedings. Otherwise, the secondary sources below that are marked with an asterisk $\left(^{*}\right)$ were used for such data, or the best available estimates.

In Figure 3, estimates for the Maccabees, Royal Arcanum, and German National Alliance were made from substantial but incomplete data on membership and state foundings. Figure 3 omits 4 of the 34 federal-state-local associations in Table 1. The American Anti-Slavery Society, the Colored Farmers' Alliance, and the American Protective Association were excluded from the figure because they were short-lived, regionally centered, and never reached $60 \%$ of states; for the American Automobile Association, we have not yet obtained founding dates for state associations.

American Anti-Slavery Society: American Anti-Slavery Society 1834; Myers 1961.

American Automobile Association: American Automobile Association 1952; Partridge 1952.

American Bowling Congress: Matzelle and Schneider 1995; American Bowling Congress 1999.

American Farm Bureau Federation: Hansen 1991; Kile 1921. American Federation of Labor: Taft 1957.

American Legion: Pencak 1989.

American Protective Association: *Desmond 1912; *Kinzer 1964.

\footnotetext{
${ }_{13}$ For arguments along these lines, see Ganz 1994, Rosenstone and Hansen 1993, Schier 2000, Skocpol 1999, and Weir and Ganz 1997. For a variety of other perspectives on contemporary civic transformations, see Berry 1999, Minkoff 1997, Putnam 2000, Schudson 1998, and Wuthnow 1998.
} 
American Red Cross: Davidson 1950a, 1950b.

American Temperance Society: Krout 1925.

Ancient and Accepted Free Masons: Stillson 1926.

Ancient Order of United Workmen [AOUW]: Stevens 1899, 128-30; Upchurch 1887.

Benevolent and Protective Order of Elks: Nicholson, Donaldson, and Dobson 1978.

Boy Scouts of America: Macleod 1983; Murray 1937.

Christian Endeavor: Clark 1906; United Society of Christian Endeavor 1892.

Colored Farmers' Alliance: *Abromowitz 1950; Dunning 1891; *Holmes 1975.

Congress of Industrial Organizations: Zieger 1995.

Farmers' Alliance: Dunning 1891; Hicks 1935; McMath 1975.

Fraternal Order of Eagles: Fraternal Order of Eagles 1913; O'Reilly 1904.

General Federation of Women's Clubs: Croly 1898; Wells 1953.

General Union for Promoting the Observance of the Christina Sabbath: General Union 1828; *John 1995, chap. 5.

German National Alliance: *Child 1939; *Committee on the Judiciary, U.S. Senate 1918.

Grand Army of the Republic: Beath 1889; McConnell 1992.

Improved Order of Red Men: Lichtman 1901.

Independent Order of Good Templars: Newton 1869; Turnbull 1901.

Independent Order of Odd Fellows: Independent Order 1844; Stillson (1897).

Junior Order of United American Mechanics: Deemer, Shanor, and Deily 1896.

Knights of Columbus: Kaufman 1982.

Knights of Labor of North America: Knights of Labor 1883; Voss 1993.

Knights of Pythias: Carnahan 1890.

Ku Klux Klan: *Chalmers 1965; * MacLean 1994.

Loyal Order of Moose: Fuller 1918; Loyal Order of Moose 1943.

Maccabees: Knights of the Maccabees 1894, *1901; *Stevens 1899, 151-4.

Modern Woodmen of America: Modern Woodmen 1999; Stevens 1899, 157-9.

National American Woman's Sufferage Association: Banaszak 1996; *Lemons 1973, 52-3. These sources disagree about NAWSA's size; we accept the latter's estimate that it briefly ballooned to about 2 million just as the constitutional amendment enshrining female suffrage was adopted in 1920.

National Congress of Mothers [PTA]: National Congress of Parents and Teachers 1947.

Nobles of the Mystic Shrine: Melish et al. 1919.

Old Age Revolving Pensions, Ltd. (Townsend movement): Holtzman 1963.

Order of the Eastern Star: Engle 1912; Stillson 1926, 857-68.

Patrons of Husbandry (National Grange): Howard 1992; Nordin (1974).

Royal Arcanum: *Royal Arcanum 1901; *Stevens 1899, $186-7$.

Sons of Temperance: Beattie 1966; Hodges 1877.

Washington Temperance Societies: Grosh 1842; *Maxwell 1950.

Woman's Christian Temperance Union: Bordin 1981; Mezvinsky 1959; Tyler 1949.

Woman's Missionary Union: Allen 1987.

Woodmen of the World: Larson and Cook 1991.

Young Men's Christian Association: Hopkins 1951.

\section{APPENDIX B: CITY DIRECTORY DATA}

Tables 3 and 4 are based on counts of membership-based associations listed in city directories for the dates specified in each table, and the definitions used to classify groups are given in the note to Table 3 . Around 1900, U.S. city directories were compiled by local companies that came and went, which means they did a reasonable job of including groups of local interest but did not always cover exactly the same kinds of groups in equal detail. Although there was considerable imitation in formats from city to city and company to company, in order for valid comparisons to be made across time and place, directories must be scrutinized carefully to make sure they include the same kinds of groups. We have done this and taken some steps to correct for blatant omissions.

Labor groups were not always included in these directories. The Boston directory of 1910-11, for example, simply omitted most trade unions; we used instead a full list published by the Massachusetts Bureau of Statistics (1910). Scranton, Pennsylvania, directories included unions in 1900 but in 1910 referred readers elsewhere for a full listing. Without access to the other source, we estimated Scranton unions in 1910 as the 1900 number (which was very close to the 1920 number). We have not been able to correct for obvious omissions of unions in other directories, such as those for Des Moines, Iowa, and Troy, New York.

African American associations were erratically included in the directories for Rome, Georgia. Our counts for churches in Rome include African American congregations, which were consistently listed under a separate heading in every directory we used for the 1890 to 1920 period. But African American fraternal groups were listed in only one of the four directories used for Table 4, so we excluded them in order to maintain comparable coverage and to avoid overestimating unstable groups in this city.

\section{REFERENCES}

Abromowitz, Jack. 1950. "The Negro in Agrarian Revolt." Agricultural History 24 (April): 89-95.

Aldrich, John H. 1995. Why Parties? The Origin and Transformation of Political Parties in America. Chicago: University of Chicago Press.

Allen, Catherine B. 1987. A Century to Celebrate: History of Woman's Missionary Union. Birmingham, AL: Woman's Missionary Union. Almond, Gabriel A., and Sidney Verba. 1963. The Civic Culture: Political Attitudes and Democracy in Five Nations. Princeton, NJ: Princeton University Press.

American Anti-Slavery Society. 1834. Annual Report of the American Anti-Slavery Society. New York: American Anti-Slavery Society.

American Automobile Association. 1952. The Motor Club Movement in the United States. American Automobile Association.

American Bowling Congress. 1999. Memorandum from national office, containing excerpts from original 1906-07 constitution and excerpts on later changes affecting states.

Banaszak, Lee Ann. 1996. Why Movements Succeed or Fail: Opportunity, Culture, and the Struggle for Woman Suffrage. Princeton, NJ: Princeton University Press.

Beath, Robert B. 1889. History of the Grand Army of the Republic. New York: Bryan Taylor.

Beattie, Donald Weldon. 1966. "Sons of Temperance: Pioneers in Total Abstinence and 'Constitutional Prohibition.'" Ph.D. diss. Department of Sociology, Boston University.

Beem, Christopher. 1999. The Necessity of Politics: Reclaiming American Public Life. Chicago: University of Chicago Press.

Bender, Thomas. 1978. Community and Social Change in America. Baltimore, MD: Johns Hopkins University Press.

Berman, Sheri. 1997. "Civil Society and Political Institutionalization." American Behavioral Scientist 40 (March/April): 562-74.

Berry, Jeffrey M. 1999. The New Liberalism: The Rising Power of Citizen Groups. Washington, DC: Brookings Institution Press. 
Berthoff, Roland. 1971. An Unsettled People: Social Order and Disorder in American History. New York: Harper and Row.

Bordin, Ruth. 1981. Woman and Temperance: The Quest for Power and Liberty, 1873-1900. Philadelphia, PA: Temple University Press.

Bordin, Ruth. 1986. Frances Willard: A Biography. Chapel Hill: University of North Carolina Press.

Breckinridge, Sophinisba. 1933. Women in the Twentieth"Century: A Study of Their Political, Social, and Economic Activities. New York: McGraw-Hill.

Brockett, Linus Pierpont. 1864. The Philanthropic Results of the War in America. New York: Sheldon.

$\rightarrow$ Brown, Richard D. 1974. "The Emergence of Urban Society in Rural Massachusetts, 1760-1830." Journal of American History 61 (1): $29-51$.

Bryce, James. 1895. The American Commonwealth, 3d ed. Vol. 2. New York: Macmillan.

Carnahan, James R. 1890. Pythian Knighthood: Its History and Literature. Cincinnati: Pettibone Manufacturing/Fraternity.

Chalmers, David M. 1965. Hooded Americanism: The First Century of the Ku Klux Klan, 1865-1965. New York: Doubleday.

Child, Clifton James. 1939. The German Americans in Politics, 1914-1917. Madison: University of Wisconsin Press.

Chudacoff, Howard. 1972. Mobile Americans: Residential and Social Mobility in Omaha, 1880-1920. New York: Oxford University Press.

Clark, Francis E. 1906. Christian Endeavor in All Lands: A Record of Twenty-Five Years of Progress. Boston: United Society of Christian Endeavor.

Clawson, Mary Ann. 1989. Constructing Brotherhood: Gender, Class, and Fraternalism. Princeton, NJ: Princeton University Press.

Clemens, Elisabeth S. 1997. The People's Lobby: Organizational Innovation and the Rise of Interest Group Politics in the United States, 1890-1925. Chicago: University of Chicago Press.

Committee on the Judiciary, U.S. Senate. 1918. "National GermanAmerican Alliance Hearings ... United States Senate, Sixty-Fifth Congress, Second Session on S. 3529 ..., February 23-April 13, 1918." Washington, DC: U.S. Government Printing Office.

Croly, Jennie June. 1898. The History of the Women's Club Movement in America. New York: Henry G. Allen.

$\rightarrow$ Curtis, James E., Edward G. Grabb, and Douglas E. Baer. 1992. "Voluntary Association Membership in Fifteen Countries." American Sociological Review 57 (2): 139-52.

Dannenbaum, Jed. 1984. Drink and Disorder: Temperance Reform from the Washingtonian Revival to the WCTU. Urbana: University of Illinois Press.

Davidson, Walter. 1950a. History of the American National Red Cross. Vol. 38. State Organization and Relations within the Period of Congressional Charter.... Washington, DC: American National Red Cross.

Davidson, Walter. 1950b. History of the American National Red Cross. Vol. 39. General Organization. Washington, DC: American National Red Cross.

Deemer, Edward S., P. A. Shanor, and H. J. Deily. 1896. History of the Junior Order, United American Mechanics. Boston: Fraternity.

Desmond, Humphrey J. 1912. The A.P.A. Movement: A Sketch. Washington, DC: New Century Press.

Drucker, Peter F. 1993. The Ecological Vision: Reflections on the American Condition. New Brunswick, NJ: Rutgers University Press.

Dunning, N. A., ed. 1891. The Farmers' Alliance History and Agricultural Digest. Washington, DC: Alliance.

Eckstein, Harry. 1961. A Theory of Stable Democracy. Research Monograph No. 10. Princeton, NJ: Center for International Studies, Princeton University.

Engle, Willis D. 1912. History of the Order of Eastern Star. Indianapolis, IN.

Evans, Peter, ed. 1997. State-Society Synergy: Government and Social Capital in Development. Research Series, Number 94, International and Areas Studies. Berkeley: University of California.

Fahey, David M. 1996. Temperance and Racism. Lexington: University Press of Kentucky.

$\rightarrow$ Foley, Michael W., and Bob Edwards. 1999. "Is It Time to Disinvest in Social Capital?" Journal of Public Policy 19 (2): 141-73.

Fraternal Order of Eagles. 1913. Constitution and Laws of the Grand
Aerie and Constitution for Subordinate Aeries Fraternal Order of Eagles. Chicago: Attwell.

Fuller, Guy H., ed. 1918. Loyal Order of Moose and Mooseheart. Mooseheart, IL: Mooseheart Press.

Gamm, Gerald, and Robert D. Putnam. 1999. "The Growth of Voluntary Associations in America, 1840-1940." Journal of Interdisciplinary History 29 (Spring): 511-57.

Ganz, Marshall. 1994. "Voters in the Crosshairs: How Technology and the Market Are Destroying Politics." American Prospect no. 16 (Winter): 100-9.

General Union for Promoting the Observance of the Christian Sabbath. 1828. "The Address of the General Union ... Accompanied by Minutes of ... Its Formation, Its Constitution and Officers." New York: Daniel Fanshaw.

Grosh, A. B. 1842. Washingtonian Pocket Companion, 2d ed. Utica, NY: R. W. Roberts.

Hall, Patricia Kelly, and Steven Ruggles. 1999. "Moving through Time: Internal Migration Patterns of Americans, 1850-1990." Presented at the Social Science History Association, Fort Worth, Texas, November.

Hall, Peter A., and Rosemary C.R. Taylor. 1996. "Political Science and the Three New Institutionalisms." Political Studies 44 (December): $936-57$

Hansen, John Mark. 1991. Gaining Access: Congress and the Farm Lobby, 1919-1981. Chicago: University of Chicago Press.

Hicks, John D. 1935. The Populist Revolt: A History of the Farmers' Alliance and the People's Party. Minneapolis: University of Minnesota Press.

Hodges, Samuel W. 1877 "Sons of Temperance--Historical Record of the Order." In Centennial Temperance Volume. New York: National Temperance Society and Publication House. Pp. 544-98.

Holmes, William F. 1975. "The Demise of the Colored Farmers' Alliance." Journal of Southern History 41 (May): 187-200.

Holtzman, Abraham. 1963. The Townsend Movement. New York: Bookman.

Hopkins, Charles Howard. 1951. History of the Y.M.C.A. in North America. New York: Association Press.

Howard, David M. 1992. People, Pride and Progress: 125 Years of the Grange in America. Washington, DC: National Grange.

Independent Order of Odd Fellows [IOOF]. 1844. Journal of Proceedings of the Right Worthy Grand Lodge of the Independent Order of Odd Fellows ... to the Close of the Annual Session, 1843. ..." New York: McGowan and Treadwell.

John, Richard. 1995. Spreading the News: The American Postal System from Franklin to Morse. Cambridge, MA: Harvard University Press.

Joyce, Michael S., and William A. Schambra. 1996. "A New Civic Life." In To Empower People, 2d ed., ed. Michael Novak. Washington, DC: AEI Press. Pp. 11-29.

Kaufman, Christopher J. 1982. Faith and Fraternalism: The History of the Knights of Columbus, 1882-1992. New York: Harper and Row.

Kinzer, Donald L. 1964. An Episode in Anti-Catholicism: The American Protective Association. Seattle: University of Washington Press.

Kile, Orville Merton. 1921. The Farm Bureau Movement. New York: Macmillan.

$\rightarrow$ Kitschelt, Herbert P. 1986. "Political Opportunity Structures and Political Protest: Anti-Nuclear Movements in Four Democracies." British Journal of Political Science 16 (January): 57-85.

Knights of Labor of North America. 1883. Constitution of the General Assembly, District Assemblies and Local Assemblies of the Order of the Knights of Labor of North America. Marblehead, MA: Statesman.

Knights of the Maccabees. 1894. Revised Laws of the Knights of the Maccabees of the World.... Port Huron, MI: Riverside.

Knights of the Maccabees. 1901. "Note the Progress of the Maccabees" (reverse side of a postcard). Port Huron, MI: General Offices [of the Maccabees].

Kopf, Edward. 1977. "Untarnishing the Dream: Mobility, Opportunity, and Order in Modern America." Journal of Social History 11 (Winter): 202-27.

Krout, John Allen. 1925. The Origins of Prohibition. New York: Alfred Knopf.

Ladd, Everett Carl. 1999. The Ladd Report. New York: Free Press. Larson, Leland A., and James R. Cook. 1991. The Woodmen Story: 
"Our First 100 Years." Updated edition. Woodmen of the World Life Insurance Society.

Lemons, J. Stanley. 1973. The Woman Citizen. Urbana: University of Illinois Press.

Levi, Margaret. 1996. "Social and Unsocial Capital." Politics and Society 24 (March): 45-55.

Lichtman, Charles H., ed. 1901. Official History of the Improved Order of Red Men, rev. ed. Boston: Fraternity.

Loyal Order of Moose. 1943. Laws for the Institution and Regulation of Member Lodges.

MacLean, Nancy. 1994. Behind the Mask of Chivalry: The Making of the Second Ku Klux Klan. New York: Oxford University Press.

Macleod, David. 1983. Building Character in the American Boy: The Boy Scouts, YMCA, and the Forerunners, 1870-1920. Madison: University of Wisconsin Press.

Martinek, Joseph. 1985. One Hundred Years of the CSA: The History of the Czechoslovak Society of America, trans. R. A. Gorman. Cicero, IL: Executive Committee of CSA.

Massachusetts Bureau of Statistics. 1910. Directory of Labor Organizations in Massachusetts, 1910. Labor Bulletin No. 76. Boston: Wright and Potter.

$\rightarrow$ Mathews, Donald G. 1969. "The Second Great Awakening as an Organizing Process, 1780-1830: An Hypothesis." American Quarterly 21 (Spring): 23-43.

Matzelle, Al, and Jerry Schneider. 1995. History of the American Bowling Congress. American Bowling Congress.

Maxwell, Milton. 1950. "The Washingtonian Movement." Quarterly Journal Studies on Alcohol 11 (3): 410-51.

McConnell, Stuart. 1992. Glorious Contentment: The Grand Army of the Republic, 1865-1900. Chapel Hill: University of North Carolina Press.

McGerr, Michael E. 1986. The Decline of Popular Politics: The American North, 1865-1928. Oxford and New York: Oxford University Press.

McMath, Robert C., Jr. 1975. Populist Vanguard: A History of the Southern Farmers' Alliance. Chapel Hill: University of North Carolina Press.

McPherson, James M. 1988. Battle Cry of Freedom: The Civil War Era. New York: Ballentine.

Melish, William B., et al. 1919. The History of the Imperial Council Ancient Arabic Order Nobles of the Mystic Shrine for North America, 1872-1919. Cincinnati, OH: Committee on History, Imperial Council Nobles of the Mystic Shrine.

Mezvinsky, Norton. 1959. "The White-Ribbon Reform: 1874-1920." Ph.D. diss. Department of History, University of Wisconsin.

Minkoff, Debra C. 1997. "Producing Social Capital: National Movements and Civil Society." American Behavioral Scientist 40 (March/ April): 606-19.

Modern Woodmen of America. 1999. Letter from historian Gail Ann Levis about historical changes in the association's constitution.

Murray, William D. 1937. History of the Boy Scouts in America. New York: Boy Scouts.

Myers, John Lytle. 1961. "The Agency System of the Anti-Slavery Movement, 1832-1837. ..." Ph.D. diss. Department of History, University of Michigan.

National Congress of Parents and Teachers. 1947. Golden Jubilee History, 1897-1947. Chicago: National Congress of Parents and Teachers.

Newton, Pierce I. 1869. The History of the Independent Order of Good Templars. Philadelphia, PA: Daughaday and Becker.

Nicholson, James R., Lee A. Donaldson, and Raymond C. Dobson. 1978. History of the Order of Elks, 1868-1978, rev. ed. Chicago: Grand Secretary's Office of the Benevolent and Protective Order of Elks of the United States of America.

Nordin, Sven D. 1974. Rich Harvest: A History of the Grange, 1867-1900. Jackson: University of Mississippi Press.

O'Reilly, J. Fanning. 1904. History of the Fraternal Order of Eagles. New York: Press of M. Schlesinger.

Palmer, Edward Nelson. 1944. "Negro Secret Societies." Social Forces 23 (December): 207-12.

Partridge, Bellamy. 1952. Fill 'er Up! The Story of Fifty Years of Motoring. New York: McGraw-Hill.

Pencak, William. 1989. For God and Country: The American Legion, 1919-1941. Boston: Northeastern University Press.

Powell, Walter W., and Paul J. DiMaggio, eds. 1991. The New
Institutionalism in Organizational Analysis. Chicago: University of Chicago Press.

Preuss, Arthur R. 1924. A Dictionary of Secret and Other Societies. St. Louis, MO: Herder.

Putnam, Robert D. 1993. Making Democracy Work: Civic Traditions in Modern Italy. Princeton, NJ: Princeton University Press.

Putnam, Robert D. 2000. Bowling Alone: The Collapse and Revival of American Community. New York: Simon and Schuster.

Ridge, John T. 1986. Erin's Sons in America: The Ancient Order of Hibernians. New York: AOH Publications.

Rosenstone, Steven J., and John Mark Hansen. 1993. Mobilization, Participation, and Democracy in America. New York: Macmillan.

Royal, David. [1890s] n.d. "Introduction of the Order of Knights of Pythias in the Grand Domain of Minnesota." Knights of Pythias archives, Quincy, Massachusetts.

Royal Arcanum. 1901. The Code of Constitutions and Laws of the Royal Arcanum. . . . Boston, MA: Supreme Council [of the Royal Arcanum].

Ryan, Mary P. 1997. Civic Wars: Democracy and Public Life in the American City during the Nineteenth Century. Berkeley and Los Angeles: University of California Press.

Sandel, Michael J. 1996. Democracy's Discontent: America in Search of a Public Philosophy. Cambridge, MA: Harvard University Press.

Schier, Steven E. 2000. By Invitation Only: The Rise of Exclusive Politics in the United States. Pittsburgh, PA: University of Pittsburgh Press.

Schlesinger, Arthur M. [Sr.] 1944. "Biography of a Nation of Joiners." American Historical Review 50 (October): 1-25.

Schmidt, Alvin J. 1980. Fraternal Organizations. Westport, CT: Greenwood.

Schudson, Michael. 1998. The Good Citizen: A History of American Civic Life. New York: Free Press.

Shefter, Martin. 1994. Political Parties and the State: The American Historical Experience. Princeton, NJ: Princeton University Press.

Skocpol, Theda. 1992. Protecting Soldiers and Mothers: The Political Origins of Social Policy in the United States. Cambridge, MA: Harvard University Press.

Skocpol, Theda. 1999. "Advocates without Members: The Recent Transformation of American Civic Life." In Civic Engagement in American Democracy, ed. Theda Skocpol and Morris P. Fiorina. Washington, DC: Brookings Institution Press, and New York: Russell Sage Foundation. Pp. 461-509.

Skocpol, Theda, et al. 1999. "How Americans Became Civic." In Civic Engagement in American Democracy, ed. Theda Skocpol and Morris P. Fiorina. Washington, DC: Brookings Institution Press, and New York: Russell Sage Foundation. Pp. 27-80.

Stevens, Albert. C. 1899. The Cyclopedia of Fraternities. New York: Hamilton Printing and Publishing.

Stillson, Henry Leonard. 1897. The History and Literature of Odd Fellowship. Boston, MA: Fraternity.

Stillson, Henry Leonard, ed. 1926. History of the Ancient and Honorable Fraternity of Free and Accepted Masons and Concordant Orders. Boston: Fraternity.

Taft, Philip. 1957. The A.F.L. in the Time of Gompers. New York: Harper and Brothers.

Tarrow, Sidney. 1996a. "Making Social Science Work across Space and Time: A Critical Reflection on Robert Putnam's Making Democracy Work." American Political Science Review 90 (June): 389-97.

Tarrow, Sidney. 1996b. "States and Opportunities: The Political Structuring of Social Movements." In Comparative Perspectives on Social Movements, ed. Doug McAdam, John D. McCarthy, and Mayer N. Zald. Cambridge: Cambridge University Press.

Tocqueville, Alexis de. [1835-40] 1969. Democracy in America, ed. J. P. Mayer, trans. George Lawrence. Garden City, NY: Doubleday, Anchor.

Turnbull, William W. 1901. The Good Templars. Arlington, MA: printed privately.

Tyler, Alice Felt. 1944. Freedom's Ferment. Minneapolis: University of Minnesota Press.

Tyler, Helen E. 1949. Where Prayer and Purpose Meet: The WCTU Story, 1874-1949. Evanston, IL: Signal.

United Society of Christian Endeavor. 1892. The United Society of Christian Endeavor: State and Local Unions. Boston, MA: United Society of Christian Endeavor. 
Upchurch, J. J. 1887. The Life, Labors and Travels of Father J. J. Upchurch, Founder of the Ancient Order of United Workmen, ed. Sam Booth. San Francisco, CA: A. T. Dewey.

Voss, Kim. 1993. The Making of American Exceptionalism: The Knights of Labor and Class Formation in the Nineteenth Century. Ithaca, NY: Cornell University Press.

Weir, Margaret, and Marshall Ganz. 1997. "Reconnecting People and Politics." In The New Majority, ed. Stanley B. Greenberg and Theda Skocpol. New Haven, CT: Yale University Press. Pp. 149-71.

Wells, Mildred White. 1953. Unity in Diversity: The History of the
General Federation of Women's Clubs. Washington, DC: General Federation of Women's Clubs.

Wiebe, Robert H. 1967. The Search for Order, 1877-1920. New York: Hill and Wang.

Will, George. 1995. "Look at All the Lonely Bowlers." Washington Post, January 5, p. A29.

Wuthnow, Robert. 1998. Loose Connections: Joining Together in America's Fragmented Communities. Cambridge, MA: Harvard University Press.

Zieger, Robert H. 1995. The CIO 1935-1955. Chapel Hill: University of North Carolina Press. 